\title{
THE FOURTH AMENDMENT IN THE TWENTY-FIRST CENTURY: TECHNOLOGY, PRIVACY, AND HUMAN EMOTIONS
}

\author{
ANDREW E. TASLITZ*
}

I

\section{INTRODUCTION}

On July 3, 2001, the Tampa, Florida, Police Department began using FaceIt, a video surveillance system based on face-recognition software, in Ybor City, a downtown nightlife district. ${ }^{1}$ Three dozen security cameras scanned crowds while the software, using complex mathematical formulas to represent facial features, searched for database matches to the faces of wanted criminals. ${ }^{2}$ When no match was found, the scanned image was deleted, a precaution voluntarily undertaken by the system's owner, Visionics Corporation of Jersey City, New Jersey, but not required by law. If a match was found, however, a systems operator would then determine whether there was enough of a match to notify a uniformed officer to investigate and possibly make an arrest. ${ }^{4}$ Signs in the area warned passersby, "Smart CCTV in use," though most interviewed for a news story on the system did not know what the message meant. ${ }^{5}$ Meanwhile, the Pentagon is funding a fifty-million dollar initiative to use face-recognition technology as a means for combating terrorism. ${ }^{6}$

Informal interviews revealed widely diverging views of the technology among Tampa's citizenry. Many saw it as an invasion of privacy reminiscent of George Orwell's 1984, which predicted a totalitarian future based on constant,

Copyright (C) 2002 by Andrew E. Taslitz

This article is also available at http://www.law.duke.edu/journals/65LCPTaslitz.

* Professor, Howard University School of Law.

The author expresses his thanks to Professors Robert Mosteller, Margaret Paris, and Christopher Slobogin for their comments on earlier drafts of this article and to his research assistants, Nia Ayanna, Nebbiat Baarez, and Semira Asfaha. Special thanks goes as well to Professor James Coleman and the Law and Contemporary Problems staff editors and Board for inviting me to participate in this symposium on Individual Rights in the Twenty-First Century.

1. Dana Canedy, Tampa Scans the Faces of Its Crowds for Criminals, N.Y. TimES, July 4, 2001, at A1, A11.

2. Id.

3. Id.

4. $I d$.

5. $I d$.

6. David Callahan, Questions of Identity: Overmatched by Technology, WASH. PosT, July 22, 2001, at B3. 
state-initiated surveillance of its subjects. ${ }^{7}$ Police and local political officials argued that the system promotes safety, but privacy advocates objected to the city's recording or utilizing facial images without the victims' consent, ${ }^{8}$ some staging protests against the FaceIt system. ${ }^{9}$

Privacy objections seem to be far more widely shared than this small protest might suggest. The objectors cover the entire political spectrum. House Majority Leader Richard Armey, for example, in asking for a report on federal surveillance spending, had this to say about the subject:

The most serious threats to our freedom often advance in small steps. Face recognition systems may one day provide significant benefits in military applications.... We are taking a step in the wrong direction if we allow this powerful technology to be turned against citizens who have done no wrong. ${ }^{10}$

7. Canedy, supra note 1 , at A1.

8. Id.

9. $I d$.

10. Id.; see also Robert O'Harrow, Jr., Matching Faces with Mug Shots; Software for Police, Others Stir Privacy Concerns, WASH. POST, Aug. 1, 2001, at A1, A6. It is unclear, however, whether Representative Armey or the Ybor City protestors would maintain their level of indignation about video surveillance after the September 11, 2001 terrorist attacks on the World Trade Center and the Pentagon. See Timothy Egan, Surveillance: From "Big Brother" to Safety Tool, N.Y. TIMES, Dec. 6, 2001, at B1. Mr. Egan opines:

Before September 11, the idea that Americans would submit to round-the-clock electronic surveillance on streets and public walkways seemed remote. Only six months ago, after Tampa, Fla. became the first city in the country to install face recognition cameras for routine surveillance, it set off loud protests. People wearing Groucho Marx glasses to defy the cameras joined conservative social critics in decrying a new era of optical omniscience. But now some people who once thought surveillance cameras were inconsistent with the values of an open society have tentatively embraced them.

$I d$. at B1. If indignation has indeed dimmed, that may be the result of fear, panic, and the rush to take action rather than of a diminution in the value that Americans will continue to ascribe to privacy. See $i d$. at B8 (quoting Reba McIanan, the only Virginia Beach, Virginia council member voting against use of video surveillance: "While everyone wants to do something after the September 11 attacks, my concern is that in the rush to do something, we have created something we may ultimately regret."). Furthermore, some Americans may mistakenly believe that increased security necessarily requires sacrificing civil liberties. See, e.g., Lisa Guernsey, Living Under an Electronic Eye: As Terror Reshapes the Privacy Debate, the Government Seeks Broader Access to Data, N.Y. TimES, Sept. 27, 2001, at F1, F8 (relying on polling data and interviews suggesting that after September 11, Americans are more willing to sacrifice civil liberties for security); John Schwartz, Silver Bullet-ism: Technology Runs to the Rescue, N.Y. TIMES, Dec. 9, 2001, at WK3 (recounting danger that relying on increased technological surveillance to enhance public safety may be "betting on the wrong horse"). Thus, Kevin Watson, a spokesman for the Law Enforcement Alliance of America, which represents 65,000 crime victims and active and retired police officers, describes video surveillance systems as "bad law enforcement" because they are "tool[s] that [take] police officers out of the community and [make] them look like... pawn[s] of Big Brother." Egan, supra, at B8. Furthermore, that tool, while reducing community involvement and trust, may do little to catch terrorists. See id. (noting that none of the World Trade Center or Pentagon hijackers' images was part of the database of images stored in Tampa's system); Schwartz, supra, at WK3 (describing face-recognition systems as a "flawed technology"). More generally, a focus on enhancing technological surveillance can divert resources from better ways to protect public safety:

The ultimate goal ... should be improving the hardiness of a nation's infrastructure, creating buildings less likely to collapse and planes less likely to crash, and devising standards that keep weapons like bombs and bugs (biological and computer-related) from being built. And this can be accomplished only by patiently, thoroughly rethinking how society functions.

Id. at WK3 (quoting Edward Tenner, a visiting researcher at Princeton University and author of WHY Things Bite BACK: TECHNOLOGY AND THE REVENGE OF UNINTENDED CONSEQUENCES (1997)). 
The American Civil Liberties Union has joined Armey's call for caution, describing the FaceIt system as subjecting the public to a "digital lineup." Others worry that FaceIt and similar systems will be used by government agencies to track and catalogue the movements of innocent citizens, possibly for political reasons. ${ }^{12}$ Little, if any, legislation protects against these dangers, yet it is unlikely that the Fourth Amendment to the United States Constitution does either. The wisdom of implementing the system has not yet been subjected to serious democratic deliberation. ${ }^{13}$

The FaceIt system represents the tip of the iceberg in the growing potential use of surveillance technologies, including "ray-gun distance frisks," tory, nationwide DNA databases covering all United States residents, ${ }^{15}$ longdistance, hard-to-detect cyber-searches, ${ }^{16}$ retinal scanning ${ }^{17}$ and radioactive "tag" alerts. ${ }^{18}$ This list sounds like far-fetched science fiction, but all of these

I am not taking a position on when, if ever, a particular technology like face-recognition systems should be used and, if so, how. But I am arguing that privacy values are implicated in using such systems and merit great weight, even if the majority of a fearful public might in haste be willing too easily to sacrifice those values. See infra Part III. We should first search for equally effective alternatives. Nor do the events of September 11 alter these positions, as I explain in this article's conclusion. See infra Part IV. A better solution is to recognize the constitutional nature of the problem and involve an informed public in multi-branch efforts to protect both public safety and privacy.

11. O'Harrow, supra note 10, at A1, A6.

12. See id. at A6.

13. See Callahan, supra note 6 ("Law enforcement agencies operate in a poorly regulated environment, ... installing video surveillance systems without public notification, consultation, or debate").

14. Joel Siegel, Hil Sez Rudy Refuses to See Problems with N.Y.P.D., DAILY NeWs, Mar. 6, 2000, at 26 (reporting Hillary Clinton's suggestion that a soon-to-be-perfected concealed weapons detector could help police avoid mistakenly using deadly force); see also Fox Butterfield, Justice Dept. Awarding Grants to Develop Gun Detectors, N.Y. TIMES, Mar. 10, 1995, at A22 (reporting that the Justice Department received $\$ 2.15$ million to develop gun detectors); see generally David A. Harris, Superman's $X$-Ray Vision and the Fourth Amendment: The New Gun Detection Technology, 69 TEMP. L. REV. 1 (1996).

15. See generally David H. Kaye et al., Is a DNA Identification Database in Your Future?, 16 CRIM.

J. 4 (2001) (favoring a comprehensive, population-wide DNA database).

16. See, e.g., Guernsey, supra note 10, at F1. Ms. Guernsey explains:

With so much public and personal business being carried out electronically, it has become technically feasible for government agencies-or anyone with the proper tools-to find private electronic correspondence without ever breaking into secret drawers, or even entering a person's home or office.

And not just e-mail can be seized. The most mundane aspects of a person's life are now recorded digitally, often in databases beyond their control. With each new technology, more details of people's daily activities can potentially be scooped up by law enforcement officials and later presented in a courtroom.

But with such surveillance capabilities, the question inevitably arises: Should the government be given the authority to use them?

Id. at F1. See also John Schwartz, Privacy Debate Focuses on FBI Use of an Internet Wiretap, N.Y. TIMES, Oct. 13, 2001, at B6 (discussing the debates over congressional bills seeking to expand the federal government's ability to monitor e-mail usage and paraphrasing former federal prosecutor and current internet security consultant Mark Rasch as cautioning that such bills are a "hasty overreaction by lawmakers" to fears of terrorism in the wake of the September 11, 2001 terrorist assaults on the World Trade Center and the Pentagon).

17. Callahan, supra note 6 .

18. See Alan Calnan \& Andrew E. Taslitz, Defusing Bomb-Blast Terrorism: A Legal Survey of Technological and Regulatory Alternatives, 67 TENN. L. REV. 177, 185-86 (1999) (describing "tagging" 
technologies are either available now or are currently being developed, and many advocates of public safety and more effective law enforcement-especially in an era of rising dangers from terrorism-favor broad implementation. ${ }^{19}$

The advance of technology has spread so far and so fast that now even federal judges face routine mass-monitoring by the state. In March 2001, the judges of the Ninth Circuit Court of Appeals learned that their computers had been monitored by the Administrative Office of the United States Courts ("AO"). ${ }^{20}$ The AO's goal had been to discourage activities unrelated to the judiciary's work, like listening to music or surfing the web for pornography. In May, the Ninth Circuit judges, outraged by this surveillance, blocked the system that allowed the monitoring of their computers. ${ }^{21}$ The judicial rebellion was led by conservative judge Alexander Kozinski, whose family escaped from thenCommunist-controlled Romania when Judge Kozinski was eleven years old. ${ }^{22}$ In computer-monitoring, Judge Kozinski was reminded of his childhood in a totalitarian regime. "I know what it's like to always be on your guard," 23 he explained in an interview. "Everything you say or do will be judged or reported, and you'll have to explain yourself for things that are really innocent." ${ }^{24}$ Though Judge Kozinski apparently maintains otherwise, there is strong reason to believe that the Ninth Circuit judiciary is not entitled to protection against this surveillance under the Fourth Amendment. ${ }^{25}$

Indeed, to read most United States Supreme Court case law under the Fourth Amendment, one would be hard-pressed to see any mention or other indication of understanding of the indignation felt by people like the protesting Ybor City residents or Judge Kozinski. The Court generally, though not always, conceives of privacy as a cognitively driven issue, divorced from human

technologies where, for example, a radioactive isotope "tag" is added to bomb fuses to enable their silent detection).

19. See id. at 180-89 (describing political pressures for the continued development of tagging technologies); JAMES X. DEMPSEY \& DAVID COLE, TERRORISM AND THE CONSTITUTION: SACRIFICING CIVIL LIBERTIES IN THE NAME OF NATIONAL SECURITY (1999) (recounting the history of efforts to erode civil liberties in order to combat terrorism); PHILIP B. HEYMANN, TERRORISM AND AMERICA: A COMMONSENSE STRATEGY FOR A DEMOCRATIC SOCIETY 105-27 (1998) (expressing concern that fear of terrorism may lead to unnecessary erosion of civil liberties); David A. Harris, Back to the Future: Are Technologically-Assisted Searches a Way to Achieve Better Police/Minority Relations (unpublished manuscript) (commenting on the status of gun-detection technologies).

20. Matt Richtel, To One Judge, Cybermonitors Bring Uneasy Memories, N.Y. TIMES, Aug. 18, 2001, at A7.

21. Id.

22. $I d$.

23. $I d$.

24. $I d$.

25. See infra text accompanying note 369. Under pressure from the Ninth Circuit and negative media coverage of the monitoring, the AO did eventually back down. Neil A. Lewis, Plan for Web Monitoring in Courts Dropped, N.Y. TIMES, Sept. 9, 2001, at A20. My analysis here is limited to the most likely interpretations of the Fourth Amendment under current United States Supreme Court case law. I am not addressing whether Judge Kozinski may have stronger statutory claims. See, e.g., Glenn George, An Invited Scrutiny of Privacy Employment and Sexual Harassment: A Review of the Unwanted Gaze: The Destruction of Privacy in America, 11 UCLA WOMEN's L.J. 107, 114-16 (2000) (briefly summarizing some of the statutory regulation of governmental monitoring and e-mail usage). 
emotion. ${ }^{26}$ The Fourth Amendment only protects "reasonable" expectations of privacy. ${ }^{27}$ What is determined to be "reasonable," however, is partly dependent on a fair assessment of the probabilities of being observed. ${ }^{28}$ Under current laws, the Ybor City residents' privacy probably was not invaded by governmental video monitoring of citizens' persons and activities. Being on a public street, the residents faced the risk of being observed by passersby, including police officers. Who did the observing, by what means, for what purposes, and for how long are factors that will likely not matter.

Similarly, the computers used by Judge Kozinski and the Ninth Circuit were not owned by them and were located at a place of employment run by the administrative arm of the national judiciary. Though their physical persons were not being watched, the judges felt the collection and dissemination of information about their computer usage was invasive, crossing personal boundaries not meant to be crossed. ${ }^{29}$ Yet the AO was in much the same position as a private employer monitoring the work of its employees. Employees use the employer's property, and the employer must ensure that its workers are serving the efficient achievement of organizational goals. Current constitutional law precedent can be read as viewing such surveillance as not impinging on any "legitimate" privacy expectations of the "employees."

To be sure, sometimes the Court's cases unavoidably address the relevance of emotions involved in governmental searches, but this is done all too rarely, and when emotions are mentioned, the ones identified are usually rendered minimally important to the Court's conclusions. ${ }^{31}$ The special emotional and political dangers raised by technological surveillance are particularly ignored. Only in cases concerning searches of the home does the Court at least implicitly embrace the affective need to be secure against Big Brother. Outside the home, however, especially on the streets, the Court offers little, if any, protection of privacy. ${ }^{32}$

The Court also tends to consider the impact of privacy invasion on the particular criminal suspect or others like him. Rarely is the impact on racial, eth-

26. See discussion infra Part II; see also Andrew E. Taslitz, Revitalizing Freedom of Movement: The Fourth Amendment and the American Passions (forthcoming 2002) [hereinafter American Passions] (using social-psychology research to shed light on the Court's approach to the role of emotions under the Fourth Amendment).

27. See Andrew E. TAslitz \& Margaret L. Paris, Constitutional Criminal Procedure 86-124 (1997) (summarizing case law).

28. See infra text accompanying notes 50-112.

29. See infra text accompanying notes 170-222, 327-74 (discussing personal boundaries and privacy).

30. See infra text accompanying notes 369-370 (summarizing the bases for this argument).

31. See Andrew E. Taslitz, Respect and the Fourth Amendment 1-16 [hereinafter Respect] (illustrating this point by examining the Court's recent decision in Atwater v. Lago Vista, 121 S. Ct. 2540 (2001)) (draft manuscript, on file with Law and Contemporary Problems).

32. See infra text accompanying notes 56-157 (commenting on the Court's technological surveillance cases, human emotion, and reduced privacy expectations outside the home); Taslitz, American Passions, supra note 26, at 15 (making similar point). See also GEORGE ORWELL, 1984 (1956) (on the metaphor of an all-seeing government as "Big Brother"). 
nic, or other socially salient groups considered. ${ }^{33}$ These narrowly defined costs are weighed against the broadly defined benefits of aggressive law enforcement to the entire society. This nearly automatic tipping of the balance in favor of the state partly stems from the Court's minimal awareness of the emotional gains to social groups, and to the political community more generally, from enthusiastic protection of privacy. ${ }^{34}$ The result—one likely to be magnified by technological surveillance-is that a disproportionate amount of the burdens of police searches are imposed on minority groups. ${ }^{35}$

It is fashionable among some academics to decry the search for privacy protection as useless. ${ }^{36}$ They often argue that it is better that the Fourth Amendment protects some other interest more easily preserved in a high-technology world, such as the interest in freedom from police "coercion" or use of force. ${ }^{37}$ Other academics try to preserve privacy's role by narrowing its scope to only the most offensive of governmental invasions. ${ }^{38}$ Neither of these two approaches is promising in a world where the technology of the twenty-first century will soon enable the state to continue narrowing the privacy that we have grown to expect while carrying out our everyday affairs. ${ }^{39}$

33. See generally Taslitz, American Passions, supra note 26 (analyzing case law on the role of group impact under the Fourth Amendment in the context of freedom of movement); Taslitz, Respect, supra note 31 (extended defense of the theory justifying such consideration).

34. See Taslitz, Respect, supra note 31, at 1-22 (importance of emotional gains for groups and the broader political community from a respect-based Fourth Amendment jurisprudence); see also infra text accompanying notes 207-87.

35. See David L. Cole, No Equal Justice: Race and Class in the American Criminal JUSTICE SYSTEM 16-62 (1999) (explaining social processes by which the Court's current definition of privacy leaves it largely out of the hands of poor urban minorities); William J. Stuntz, The Distribution of Fourth Amendment Privacy, 67 GEO. WASH. L. REV. 1265, 1267-74 (1999) (discussing the Court's current definition of privacy, which leaves it largely out of the hands of poor urban minorities) [hereinafter Distribution]; Taslitz, American Passions, supra note 26; Andrew E. Taslitz, Stories of Fourth Amendment Disrespect: From Elian to the Internment, FORDHAM L. REV. (forthcoming May 2002) (illustrating that police searches are conducted disproportionately on minority groups) [hereinafter Stories].

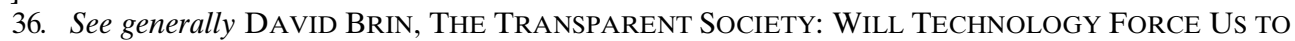
CHOOSE BETWEEN PRIVACY AND FREEDOM? (1998) (arguing that there can be little privacy in an age of high technology and high government regulation, so increased "watching of the watchers" is often a better strategy for protecting American freedoms); William J. Stuntz, Privacy's Problem and the Law of Criminal Procedure, 93 MICH. L. REV. 1016, 1071-77 (1995) [hereinafter Privacy's Problem] (arguing that given the minimal protection offered by privacy, Fourth Amendment doctrine should turn to other values).

37. See, e.g., Stuntz, Privacy's Problem, supra note 36, at 1071-77 (favoring deterrence of police violence). Cf. Scott Sundby, "Everyman's" Fourth Amendment: Privacy or Mutual Trust Between Government and Citizen?, 94 COLUM. L. REV. 1751, 1777-1802 (1994) ("trust" is a value better suited than privacy to protecting the citizenry from police overzealousness).

38. See, e.g., LAWrence Lessig, CODE AND OTHER LAWs OF CYBerspace 146 (1999) (the "utility" conception of privacy grades the degree of protection by the degree of burden imposed on tranquility); Sherry F. Colb, The Qualitative Dimension of Fourth Amendment "Reasonableness," 98 COLUM. L. REV. 1642, 1666 (1998) [hereinafter Qualitative Dimension] (arguing that Fourth Amendment privacy is more about prohibiting "direct [police] perception of individuals' physical or mental states, activities, conversations, and other personal experiences that are manifestly hidden from observation" than about informational secrecy).

39. LESSIG, supra note 38, at 146-49 (stating that, because technology reduces the burdens of invasion-for example, your tranquility cannot be disturbed if you do not know you are being watchedthe "utility conception" of privacy offers less protection against technology than do alternative concep- 
I suggest a different approach: broadening protection by redefining privacy from the primarily cognitive to the primarily affective. Privacy in the information age is best conceived as the maintenance of metaphorical boundaries that define the contours of personal identity. Identity is complex; different circumstances reveal different aspects of our nature. Each of us wears many masks wherein each mask reflects a different aspect of who we really are. We do not want our entire natures to be judged by any one mask, nor do we want partial revelations of our activities to define us in a particular situation as other than who we want to be. ${ }^{40}$ In short, we want to choose the masks that we show to others; any such loss of choice is painful, amounting almost to a physical violation of the self. ${ }^{41}$ When we are secretly watched, or when information that we choose to reveal to one audience is instead exposed to another, we lose that sense of choice. Under this conception of privacy, actions done in public can still be "private" in that we maintain our desire to retain control over who observes us, how they do so, and for what purposes. ${ }^{42}$ Similarly, the revelation of information to one person does not mean that we therefore "assume the risk" of revelation to all. ${ }^{43}$

Some academics have touched on the importance of human emotion to defining Fourth Amendment privacy. Their illuminating efforts have nevertheless been tentative, their awareness of the flawed cognitive/affective dichotomy only dimly perceived, and their theories have not been readily applicable to solving many of the problems raised by technological surveillance. ${ }^{44}$ One commentator,

e "utility conception" of privacy offers less protection against technology than do alternative conceptions).

40. The notion of multi-masked identity is elaborated infra in the text accompanying notes 180-222.

41. See infra Part III.A.2, text accompanying notes 188-98 (on the fear of misjudgment as the basis for privacy).

42. See infra Part III.C, text accompanying notes 289-326.

43. See DEMPSEY \& COLE, supra note 19, at 98 ("Under the 'invited informer' principle, the Court has reasoned that a person or organization has no legitimate expectation of privacy in information voluntarily shared with a third party in the mistaken belief that the information will not be turned over to the government."); TASLITZ \& PARIS, supra note 27, at 100, 109-19 (explaining the concept of "assumption of risk").

44. Sherry Colb critically identifies two types of emotional harms from unjustified searches and seizures: first, a "targeting harm"- the sense of stigma from being singled out from others without an adequate evidentiary basis; and, second, the humiliation of direct, personal observation of our activities by the government. Sherry Colb, Innocence, Privacy, and Targeting in Fourth Amendment Jurisprudence, 96 COLUM. L. REV. 1456, 1491-95 (1996) [hereinafter Targeting Harm] (explaining targeting harm); Colb, Qualitative Dimension, supra note 38, at 1666-69 (explaining direct governmental perception harm). Colb's analyses are insightful but inadequate to deal with the problems raised by technological surveillance. First, she offers little justification for protecting against information disclosure, such as that of data on a computer, because those types of disclosures do not involve "direct governmental perception" of our persons or activities. Second, she believes that privacy harms must be judged entirely from the perspective of the innocent (though she would extend protection against targeting harms to the guilty), which is an approach that we will soon see is inadequate, see infra Part III. Colb argues, without significant supporting social science, that the guilty have forfeited privacy rights in the areas in which they conceal evidence of wrongdoing because such concealment is morally culpable. See Colb, Targeting Harm, supra, at 1469-73. The law might nevertheless offer certain protections to all because we do not ordinarily know in advance who is innocent, who guilty. See id. at 1472. But her approach would nevertheless consider concealment guilt relevant to whether the Fourth Amendment offers any protection at all and whether, if it does, damages should be awarded. See id. at 1516-22. Colb 
on whose work I rely significantly, has done a far more thorough job of rethinking privacy affectively. ${ }^{45}$ Unfortunately, he is often vague or conclusory in applying his analysis to new police surveillance technologies, and he does not explore adequately the distributive implications of privacy concepts that disparately impact different racial, ethnic, or class groups. ${ }^{46}$ Nor has he engaged in a careful analysis of the affective missteps in the Supreme Court's technology cases. $^{47}$ I hope to fill these gaps.

I do not intend to craft specific rules for permitting particular classes of technological searches. ${ }^{48}$ I will proceed at a higher level of generality. The main danger posed to Fourth Amendment freedoms by technology stems from the Court's unduly narrow, overly cognitive conception of privacy. ${ }^{49}$ The bulk of this article therefore will wrestle with defining, defending, and exploring the implications of a more affective privacy doctrine. My primary illustrations of the implications for technological searches will be drawn from the Ybor City and Judge Kozinski examples summarized in this introduction, though I will briefly refer to other techniques where necessary.

Part II recites as examples the leading Supreme Court cases on technological searches to reveal how they demonstrate an unduly narrow and cognitive conception of privacy, though cross-currents in the case law are briefly noted. Part III outlines the contours of a more affective definition of privacy for both individuals and groups. Part III further explains how we can in fact be "pri-

thus conceives of privacy as something that one earns or loses based on culpable conduct. But I see privacy rights as central to defining individuals' humanity and group identity, things definitionally part of being a person. See infra Part III. Privacy must, of course, always be weighed against other concerns, but such balancing simply justifies sometimes invading privacy but does not dissipate privacy protections completely. See infra Part III. Furthermore, Colb's conception of the "guilty" is too broad, for example, including media efforts to protect their sources. See Colb, Targeting Harm, supra, at 1508-09. There seems to be an "intuitive" difference between not disclosing information to protect First Amendment freedoms and not doing it to hide your own complicity in a crime. More importantly, there are close historical and logical connections between Fourth and First Amendment freedoms that suggest a different approach and that Colb ignores. See generally Andrew E. Taslitz, Slaves No More!: The Implications of the Informed Citizen Ideal for Discovery Before Fourth Amendment Suppression Hearings, 15 GA. ST. L. REV. 709 (1999) [hereinafter Informed Citizen]. Finally, she unduly narrowly defines the emotional harms of privacy invasion for reasons explored infra Part III.

45. JeFFrey Rosen, THE UNWANTEd GAZE: The DESTRUCTION OF PRIVACY IN AMERICA 8-25 (2000) [hereinafter UNWANTED GAZE] (articulating a conception of privacy as control over what aspects of ourselves we reveal to others).

46. See id. at 61-65, 70-78, 89-90, 159-95 (confining his technology analysis primarily to the Internet, while ignoring many direct-observation police technologies and barely skirting the distributive problems created by current privacy conceptions). But see Stuntz, supra note 35 (explaining those same distributive consequences). Professor Rosen has more recently, in articles in the popular press, begun to pay more attention to some police technological direct surveillance methods. As of this writing, however, he has not done so in a scholarly venue, nor has he, even in popular venues, significantly examined the distributive implications of technology or the details of the case law. See Jeffrey Rosen, $A$ Watchful State, N.Y. Times MAG., Oct. 7, 2001, at 38 [hereinafter Watchful State].

47. See Rosen, supra note 45, at 61-65, 70-78, 89-90, 159-95 (barely touching upon the cases that I discuss infra Part II).

48. That task, and a comprehensive summary of the currently available and pending technologies, has already been superbly done. See Christopher Slobogin, Technologically-Assisted Physical Surveillance: The American Bar Association's Tentative Draft Standards, 10 HARV. J.L. \& TECH. 383 (1997).

49. See infra Part III (defending this argument). 
vate" in "public" and why freedom from unwanted observation and freedom from unwanted information disclosure are equally protected under a sound conception of privacy.

Finally, Part IV sets forth my recommendations for how the Court should decide cases differently under a more affective regime. My overall conclusions are that, at least in the area of electronic surveillance, the Court too readily finds no invasion of a "reasonable expectation of privacy," thus wrongly removing the police conduct at issue from any degree of constitutional regulation. Furthermore, when the Court does extend constitutional protection to certain surveillance techniques, it does not take into account in its analysis the psychological and political functions of privacy. Accordingly, in the process of crafting constitutional rules by simply weighing costs against benefits, the Court often undervalues privacy. I mean here not to impose flat prohibitions on governmental electronic surveillance, but only to increase the number of instances in which individualized suspicion, a warrant, or new sorts of limitations are required as preconditions of state-imposed monitoring.

Because my goals are only to encompass more technologically enhanced surveillance as falling within the area of privacy protections and to demonstrate privacy's continued importance, I do not resolve such troubling issues as the appropriate legal responses to terrorism, although I will briefly and necessarily touch on such issues. My purpose here is to recognize that even such issues as combating terrorism are constitutional in nature and therefore require careful consideration of underlying values that may be protected by the Fourth Amendment. Nothing in this recognition, however, stands in the way of a vigorous, aggressive, and comprehensive response to terrorism. This article draws attention to three inevitably intertwined areas that I see as raising the major Fourth Amendment challenges of the twenty-first century: technology, racial discrimination, and terrorism.

\section{II}

\section{TeCHNOLOGICAL SuRVEILLANCE AND THE Supreme COURT}

The Supreme Court has generally failed to see any enhanced dangers to privacy caused by rapidly changing police surveillance technologies. ${ }^{50}$ Instead, the Court has addressed technology questions under the same analytical framework that it uses for resolving all Fourth Amendment search questions. This framework is one that privileges the home at the expense of other venues. ${ }^{51}$ "Privacy in public," especially on the street, is an oxymoron to this Court. ${ }^{52}$ The Court's framework also readily finds that suspects "assume the risk" that any informa-

50. See infra text accompanying notes 105-31 (concluding that every United States Supreme Court technological search decision involving intrusions outside the home has granted little, if any, protection to privacy).

51. Taslitz, American Passions, supra note 32, at 15; see also infra text accompanying notes 56-157.

52. See infra text accompanying notes 105-16. 
tion disclosure becomes a revelation to many or all..$^{53}$ Perhaps most importantly, the Court's framework downplays or ignores the emotional benefits of privacy for both the individual and the larger political community. Privacy is seen by the Court as more of a cognitively driven assessment of the probabilities of observation by others in everyday life than a set of metaphorical boundaries that safeguard the affective life that defines personhood, group-hood, and community. ${ }^{54}$ There are, however, small cross-currents in the Court's body of Fourth Amendment precedent that move largely outside the technology case stream, slipping through narrow chutes elsewhere in the Court's privacy doctrine. ${ }^{55}$ These cases will be discussed as well.

\section{A. "Assuming the Risk" of Conveying Information to Third Parties}

The Court made a hopeful start toward a sound jurisprudence of privacyinvasive technology in Katz v. United States. ${ }^{56}$ There, the defendant was charged with interstate telephonic transmission of wagering information in violation of a federal statute. ${ }^{57}$ Tape recordings of Katz's end of telephone calls made from a public telephone booth were admitted at trial. The Federal Bureau of Investigation made the recordings by attaching an electronic listening and recording device to the outside of the phone booth. The Ninth Circuit Court of Appeals affirmed Katz's conviction, finding no "search" because "[t]here was no physical entrance into the area occupied by [Katz]." 58

The Supreme Court reversed. "The premise that property interests control the right of the Government to search and seize," said the Court, "has been discredited." 59 The proper test was no longer whether a trespass had occurred, but whether the electronic eavesdropping and recording "violated the privacy upon which he [Katz] justifiably relied." ${ }^{60}$ The Court held that the Government's actions therefore did constitute a "search," which implicates the Fourth Amendment. Because the search was conducted without a warrant or any exigency, the search violated the Fourth Amendment.

In Katz, the Court never defined "privacy" and was at pains to declare that the amendment does not protect a general right to privacy - a right to be let alone by other people. ${ }^{61}$ Indeed, emphasized the Court, the Amendment "protects individual privacy against [only] certain kinds of governmental intrusion,

53. DEMPSEY \& COLE, supra note 43, at 98 (using instead the term "invited informer principle"); TASLITZ \& PARIS, supra note 43, at 100, 109-19 (explaining the concept of "assumption of risk").

54. See infra text accompanying notes 56-132 (illustrating this point).

55. See infra text accompanying notes 133-56.

56. 389 U.S. 347 (1967).

57. Id.

58. Katz v. United States, 369 F.2d 130, 134 (9th Cir. 1966).

59. 389 U.S. at 353 (citing Warden v. Hayden, 387 U.S. 294, 304 (1967)).

60. $I d$.

61. Id. at 350 . 
but its protections go further, and often have nothing to do with privacy at all.",62 The Court explained:

"The average man would very likely not have his feelings soothed any more by having his property seized openly than by having it seized privately and by stealth.... And a person can be just as much, if not more, irritated, annoyed and injured by an unceremonious public arrest by a policeman as he is by a seizure in the privacy of his office or home."

Although this quote concerns property and free movement rather than privacy, its importance lies in the recognition both that the Amendment protects against certain kinds of emotional injuries and that such injuries are equally possible inside and outside the home. ${ }^{64}$ Indeed, as later cases reveal, the Court's rejection of a trespass analysis was not intended to render property relations irrelevant to search and seizure analysis. ${ }^{65}$ Trespass inquiries focus on things, not persons, and it is real, embodied persons, partly defined by a rich emotional life, that matter, "[f]or the Fourth Amendment protects people, not places."

Each person who makes phone calls from inside the closed door of a telephone booth has signaled a desire for privacy even though a glass booth allows his actions therein to be easily observable by passersby. "[W] hat he sought to exclude when he entered the booth was not the intruding eye-it was the uninvited ear." ${ }^{67}$ Indeed, though the call was made from a place subject to public observation, "[n]o less than an individual in a business office, in a friend's apartment, or in a taxicab, a person in a telephone booth may rely upon the protection of the Fourth Amendment." ${ }^{, 6}$ The Court continued:

One who occupies it, shuts the door behind him, and pays the toll that permits him to place a call is surely entitled to assume that the words he utters into the mouthpiece will not be broadcast to the world. ... To read the Constitution more narrowly is to ignore the vital role that the public telephone has come to play in private communication.

The Court's promising start in Katz was soon derailed in United States v. White, ${ }^{70}$ the Court's first post-Katz undercover agent case. In White, the government wired an informant with a radio transmitter. As White and the informant conversed, government agents listened in. ${ }^{71}$ The Court plurality's opinion rejected White's argument that Katz controlled. ${ }^{72} \mathrm{Katz}$ was distinguishable, ac-

62. Id.

63. Id. at 351 n.4 (quoting Griswold v. Connecticut, 381 U.S. 479, 509 (Black, J., dissenting)).

64. On the importance and emotional implications of impinging upon freedom of movement, see Taslitz, American Passions, supra note 26.

65. See, e.g., Daniel Yeager, Search, Seizure and the Positive Law: Expectations of Privacy Outside the Fourth Amendment, 84 J. CRIM. L. \& CRIMINOLOGY 249 (1993) (explaining the continuing relevance of property concepts and arguing for their having a stronger and more consistent role in search and seizure analysis).

66. Katz, 389 U.S. at 351.

67. Id. at 352 .

68. Id.

69. Id. (emphasis added).

70. 401 U.S. 745 (1971).

71. Id. at 748 .

72. Id. The plurality opinion, authored by Justice White, was joined by the Chief Justice and Justices Stewart and Blackmun. Justice Black concurred in the judgment and Justice Brennan filed an 
cording to the plurality, because neither party in that case had been a willing government informant. ${ }^{73}$ The Court conceded that individuals in White's situation subjectively expect privacy when they talk with informants, because they neither know nor suspect that their colleagues are "wired." ${ }^{, 74}$ That expectation, said the Court, is not legitimate. "Inescapably, one contemplating illegal activities must realize that his companions may be reporting to the police."75 Given that risk, it would be mere speculation to believe that a wrongdoer would distinguish between wired and un-wired informants or that the suspect would change his utterances for fear that his colleague is electronically monitoring the conversation. Furthermore, the state's need for this type of evidence is great:

Nor should we be too ready to erect constitutional barriers to relevant and probative evidence, which is also accurate and reliable. An electronic recording will many times produce a more reliable rendition of what a defendant has said than will the unaided memory of a police agent. It may also be that with the recording in existence it is less likely that the informant will change his mind, less chance that threat or injury will suppress unfavorable evidence and less chance that cross-examination will confound the testimony. Considerations like these obviously do not favor the defendant, but we are not prepared to hold that a defendant who has no constitutional right to exclude the informer's unaided testimony nevertheless has a Fourth Amendment privilege against a more accurate version of the events in question.

The plurality's opinion is seriously flawed in several respects. First, it is unclear why Katz was distinguished. In Katz, as in White, a suspect conveyed evidence of illegality to another party via conversation. Under the Court's logic, it would seem that the defendants in both cases undertook the risk that their illegalities would be broadcast to the police. Why should it be relevant to each respective suspect's expectation that the ultimate source of that broadcasting was the informant-accomplice rather than independent police investigation, since the ultimate outcome-disclosure of the information-is the same in both cases? Perhaps the answer is one of fairness: If the risk assumed is that the $a c$ complice will turn on the suspect, then it is somehow fair if he indeed does so but unfair if the police-whose activities are unknown to the suspect-discover the same information. ${ }^{77}$

Second, the plurality considered only the impact of the Court's holding on criminals similarly situated to White. The broader impact of its rule on political dissenters (who may or may not by their dissenting activities be criminals), un-

opinion concurring in the result; both of these latter opinions were extremely brief. See id. at 746, 75455.

73. Id. at 749 .

74. Id. at 752 .

75. $I d$.

76. Id. at 752-53.

77. See infra text accompanying notes 100-104 for a review of Justice Thurgood Marshall's position that the assumption of risk doctrine assumes some real choice by the speaker about whether to take on a particular risk. That choice is obviously lacking if one is entirely unaware that the risk one faces (police wiretapping) is at work. 



the whole idea of privacy expectations was viewed as a cognitively driven probability assessment as well as an either/or proposition: Either you had privacy (because the risks of detection of which you were or should have been aware were low) or you did not (because these risks of detection were high). ${ }^{79}$

Third, the Court balanced the state's need for the evidence against individual privacy interests in determining whether the Fourth Amendment applied at all. These considerations are more appropriately addressed under the Amendment's reasonableness balancing rubric rather than in gauging the amendment's scope. $^{80}$

Justices Douglas, Harlan, and Marshall dissented from the plurality opinion. ${ }^{81}$ Justice Harlan's dissent was especially sensitive to some of the critiques that I have made. Justice Harlan rejected what he saw as the two major assumptions of the plurality's opinion: First, that no greater invasion of privacy is involved where the government "conspires" with a third party to "betray" a suspect; and, second, that "uncontrolled electronic surveillance in an electronic age is a tolerable technique of law enforcement, given the values and goals of our political system." $\$ 2$

The flaw in the first assumption, according to Justice Harlan, was that it relied on a risk analysis that can "lead to the substitution of words for analysis."

78. For analyses of the feasibility and wisdom of considering these broader impacts of governmental searches and seizures on salient social groups and on society in general, see Taslitz, Respect, supra note 31; Taslitz, Stories, supra note 35.

79. TASLITZ \& PARIS, supra note 27 , at 100-01 (relating the doctrine of assumption of risk, implied consent notions, and other normative justifications for why a speaker should have been aware of the size and nature of a risk and its consequences).

80. The text of the Fourth Amendment itself requires that all searches and seizures be "reasonable," a word that invites balancing. See TASLITZ \& PARIS, supra note 27, at 150-57. Strong governmental interests might render many searches "reasonable" despite there being a level of suspicion that is less than probable cause and there being no warrant. See id. at 264-392 (summarizing doctrine and listing examples). But once the amendment applies, affected citizens are generally afforded at least some level of protection so that a sliding scale of privacy safeguards applies. See id. To instead consider the state's interest in the process of determining whether the amendment applies in the first place gives courts a tempting and easy out: no protection whatsoever where significant government interests are involved. That is a poor default position that too readily skirts difficult questions such as how to minimize privacy invasion without unduly sacrificing governmental objectives.

Moreover, if the Fourth Amendment is at least partly about protecting individuals' privacy expectations, the state's needs should be irrelevant to what the individual is presumptively entitled to expect. The harm to the individual remains the same regardless of the nature and size of the governmental need. Strong state needs justify some intrusions on individual expectations but do not logically defeat the existence of those expectations or their reasonableness. Rather, whether to recognize the existence of a reasonable privacy expectation is best understood as a normative question turning on fundamental notions of individual and group identity. See infra Part III.

81. 401 U.S. at 756-59. (Douglas, J., dissenting); 401 U.S. at 768 (Harlan, J., dissenting); 401 U.S. at 795 (Marshall, J., dissenting). Although the reasoning of all three dissenting opinions supports my argument here, Justice Harlan's does so most clearly and is therefore the opinion on which I focus in the greatest detail. Because I seek here only to contrast points of view that lay the groundwork for understanding the more theoretical discussion in Part III, no purpose would be served by a more detailed summary of Justices Douglas and Marshall's dissenting opinions here.

82. Id. at 785 .

83. Id. at 786 . 
The risks we assume are, in large part, reflections of laws that encourage certain customs and values. The two assumptions are thus intimately related; the normative question is ultimately the determining factor.

The individual's "sense of security," said Justice Harlan, requires more protection than "self-restraint by law enforcement officials." ${ }^{84}$ Third-party bugging undermines citizens' confidence in dealing with each other. The plurality's notion that it "is irrelevant whether secrets are revealed by the mere tattletale or the transistor" $"$ ignores the reality of human feelings and motivations:

\begin{abstract}
Authority is hardly required to support the proposition that words would be measured a good deal more carefully and communication inhibited if one suspected his conversations were being transmitted and transcribed. Were third-party bugging a prevalent practice, it might well smother that spontaneity-reflected in frivolous, impetuous, sacrilegious, and defiant discourse-that liberates daily life. Much offhand exchange is easily forgotten and one may count on the obscurity of his remarks, protected by the very fact of a limited audience, and the likelihood that the listener will either overlook or forget what is said, as well as the listener's inability to reformulate a conversation without having to contend with a documented record. All these values are sacrificed by a rule of law that permits official monitoring of private discourse limited only by the need to locate a willing assistant. ${ }^{86}$
\end{abstract}

Moreover, the gravest danger is that of having one's character misjudged by being taken out of context:

The interest... [that the risk analysis] fails to protect is the expectation of the ordinary citizen, who has never engaged in illegal conduct in his life, that he may carry on his private discourse freely, openly, and spontaneously without measuring his every word against the connotations it might carry when instantaneously heard by others unknown to him and unfamiliar with his situation or analyzed in a cold, formal record played days, months, or years after the conversation. Interposition of a warrant requirement is designed not to shield "wrongdoers," but to secure a measure of privacy and a sense of personal security throughout our society.

84. Id.

85. Id. at 787 .

86. Id. at 787-89 (emphasis added).

87. Id. at 790. Justice Harlan's use of the word "secure" at the end of this quote, and the express language of the Fourth Amendment, can arguably support a "right of security" rather than rights of privacy, property, and freedom of movement. Thomas K. Clancy, What Does the Fourth Amendment Protect: Property, Privacy, or Security?, 33 WAKE FOREST L. REV. 307 (1998). I reject this formulation for several reasons. First, I do not see what it adds to the analyses already available under the privacy, property, and free movement trilogy of interests, because Clancy defines "security" as the right to exclude the government from invading precisely these sorts of interests. See id. at 308. Second, Clancy distinguishes the motivation or reason for wanting or exercising a right from the right itself. See id. at 345. This seems to be an unsupportable, or at least impractical, distinction, because the purposes sought to be achieved by a right necessarily help to give the language of broad, general rights concrete meaning. See, e.g., TASLITZ \& PARIS, supra note 27, at 6-17 (all interpretation of vague constitutional text involves at least in part a question of guiding purposes as is revealed in varying data sources, for example from "framers' intent," American traditions, contemporary morality and attitudes, or considerations of practicality and prudence). Yet Clancy concedes that privacy, property, and free movement are the reasons or "motivations" for the right to security. Clancy, supra, at 367. Third, focusing on a unitary notion of "security" obscures the different emotional and political functions of the current trilogy. Compare Taslitz, American Passions, supra note 26 (emotional and political values served by protecting freedom of movement), with Andrew E. Taslitz, Property: The Forgotten Fourth Amendment Freedom (draft manuscript) (forthcoming 2003) (making a similar point, but concerning protection of property). Yet these different functions can also be seen as serving an overarching emotional purpose of ensuring the expression of society's respect for individuals and their salient social groups. See gener- 
Justice Harlan's warnings went unheeded by the Court eight years later in Smith v. Maryland. ${ }^{88}$ There, the telephone company, at police request, installed a pen register in Smith's home, which recorded every telephone number dialed from his phone. The police had not obtained a warrant to do so, but they nevertheless later used the pen register results and other evidence to obtain a warrant to search Smith's home. Evidence found during the subsequent search led to Smith's conviction on a robbery charge. The Supreme Court affirmed, rejecting Smith's contention that monitoring the telephone numbers that he dialed constituted a "search."

The Court doubted that people generally have a subjective expectation of privacy in the numbers that they dial. ${ }^{90}$ Dialers know that phone numbers are routed through telephone company switching equipment necessary to complete their calls and that the phone company records the numbers dialed, as on itemized phone bills. The Court said that even if Smith had a subjective expectation of privacy, that expectation was unreasonable. ${ }^{91}$ "This Court consistently has held," the majority explained, "that a person has no legitimate expectation of privacy in information he voluntarily turns over to third parties." relied on its decision in United States $v$. Miller, ${ }^{93}$ which held that a bank depositor had no legitimate expectation of privacy in financial information that he voluntarily conveyed to banks and to their employees in the ordinary course of business. The White majority approvingly cited the Miller rationale:

The depositor takes the risk, in revealing his affairs to another, that the information will be conveyed by that person to the Government.... This Court has repeatedly held that the Fourth Amendment does not prohibit the obtaining of information revealed to a third party and conveyed by him to Government authorities, even if the in-

ally, Taslitz, Respect, supra note 31 (exploring central role of respect under the Fourth Amendment). I see similar flaws in other unitary formulations of what the Fourth Amendment protects, such as Scott Sundby's idea of promoting mutual trust between the state and its citizens. Sundby, supra note 37. Though the very idea of "trust" recognizes the amendment's central affective functions, "trust" too narrowly and vaguely defines the emotional-political interests at stake. My formulation of a "respectbased jurisprudence" is also, when simply recited, vague. But my approach has the advantage of incorporating a wider range of the relevant emotions while articulating more concrete corollary principles that should better guide responses to Fourth Amendment questions without laying false claim to achieving computer-like mechanical clarity. See Taslitz, Stories, supra note 35, at 12-18 (articulating six more concrete principles of respect). Moreover, a more self-conscious focus on the relevant emotions involved in protecting the current trilogy of Fourth Amendment rights allows for further concrete specification of concerns relevant to specific problems. Thus, I argue here, for example, for protection of some level of "privacy in public"-such as when pedestrians are subjected to extended governmental video monitoring - based upon close examination of the emotional functions served by privacy. See infra text accompanying notes 289-326. In any event, the Court has long accepted the current trilogy of Fourth Amendment rights and seems unlikely to jettison entirely that scheme in the near future.

88. 442 U.S. 735 (1979).

89. Id. at 746 .

90. Id. at 743 .

91. $I d$.

92. Id. at 743-44. If the Court really means what it says in this broad statement, it is hard to see why the phone call in Katz was protected or why any phone call or other electronic transmission would be. See supra text accompanying notes 327-74 (reviewing implications if a different view of privacy is not embraced by the Court).

93. 425 U.S. 435, $442-44$ (1976). 
formation is revealed on the assumption that it will be used only for a limited purpose and the confidence placed in the third party will not be betrayed. ${ }^{94}$

The Court also rejected Smith's argument that it mattered that switching equipment, rather than the operators of an earlier day, routed the calls. The Court declared:

The switching equipment that processed these numbers... [is] merely the modern counterpart of the operator.... Petitioner concedes that if he had placed his calls through an operator, he could claim no legitimate expectation of privacy. We are not inclined to hold that a different constitutional result is required because the telephone company has decided to automate.

Justice Potter Stewart, joined by Justice Brennan, wrote a dissenting opinion. ${ }^{96}$ Justice Stewart emphasized that the source of the calls-the home-was a location entitled to unquestioned protection. ${ }^{97}$ Calls from such a location are definitively private. "I doubt," Justice Stewart opined, "there are any who would be happy to have broadcast to the world a list of the local or long distance numbers they have called." Moreover, "[t]his is not because such a list might in some sense be incriminating, but because it easily could reveal the identities of the persons and the places called, and thus reveal the most intimate details of a person's life." 99

Justice Marshall, joined by Justice Brennan, also dissented, authoring a separate opinion. ${ }^{100}$ For Marshall, just because "a phone company monitors a call for internal reasons, it does not follow that they expected this information to be made available to the public in general or the government in particular. Privacy is not a discrete commodity, possessed absolutely or not at all.",101 Moreover, implicit in the assumption of risk concept is some notion of choice. In earlier third-party surveillance cases, the defendant apparently exercised some discretion in deciding in whom to confide, but here, given that the phone "has become a personal or professional necessity," a caller "cannot help but accept the risk of surveillance." 102 To speak of assuming risks is nonsensical in "contexts where, as a practical matter, individuals have no realistic alternative." ${ }^{103}$ More importantly, risk analysis enables the government to define the scope of Fourth Amendment protections-by, for example, law enforcement's

94. White, 442 U.S. at 744 (quoting Miller, 425 U.S. at 443).

95. Id. at 745 .

96. Id. at 746 .

97. Id. at 744. If the home is used as a "commercial establishment," such as a center for drugdealing, however, the "home" loses its special protection. See Lewis v. United States, 385 U.S. 206, 211 (1966) (rejecting the argument that an undercover drug purchase in the defendant's home violated his Fourth Amendment rights, relying partly on its conclusion that when the home was converted into a "commercial center," it had no greater sanctity than a store, garage, or street).

98. 442 U.S. at 748.

99. Id.

100. Id. (Marshall, J. dissenting).

101. Id. at 749 .

102. Id. at 750 .

103. Id. 
announcing its intention to monitor phone calls-which will have a chilling effect on free expression. ${ }^{104}$

\section{B. Electronic Monitoring: Privacy in Public as an Oxymoron}

In United States $v$. Knotts, ${ }^{105}$ the Court for the first time faced the question of whether a suspect can have privacy in public. In Knotts, officers installed a battery-operated radio transmitter-a "beeper"-inside a five-gallon container of chloroform, which is often used to manufacture illegal drugs. The officers obtained the consent of the chloroform and container seller, Hawkins Chemical Company, to install the beeper. When Tristan Armstrong purchased the beeper-implanted chloroform container, the officers followed him, using visual surveillance and the beeper, to a Mr. Petschen's car. The container was transferred to that car, and Petschen drove off. When Petschen made evasive maneuvers, the officers lost him, but used the beeper to track him to a cabin. Relying on the beeper and additional information, the officers secured a search warrant, finding inside the cabin the chloroform container, a clandestine drug laboratory, and chemicals used to make amphetamine..$^{106}$

The defendant's suppression motion was denied, and he appealed his subsequent conviction, ultimately making his way to the United States Supreme Court. The Court found no invasion of a reasonable expectation of privacy. The Court held that a person traveling in an automobile on public thoroughfares has no reasonable expectation of privacy in his movements, because those movements are open to the public. ${ }^{107}$ While Knotts, the owner of the cabin, had

104. See id. at 750. Marshall made explicit his view that assumption of risk analysis should therefore be entirely normative:

In my view, whether privacy expectations are legitimate within the meaning of Katz depends not on the risks an individual can be presumed to accept when imparting information to third parties, but on the risks that he should be forced to assume in a free and open society. By its terms, the constitutional prohibition of unreasonable searches and seizures assign to the judiciary some prescriptive responsibility. As Mr. Justice Harlan, who formulated the standard the Court applies today, himself recognized: "[s]ince it is the task of the law to form and project, as well as mirror and reflect, we should not ... merely recite risks without examining the desirability of saddling them upon society."

Id. at 751 (quoting White, 401 U.S. at 786 (Harlan, J., dissenting)). See also Smith v. Maryland, 442 U.S.

735 (1979), where the Court worried about over-reliance on "subjective" expectations of privacy:

[I]f the Government were suddenly to announce on nationwide television that all homes henceforth would be subject to warrantless entry, individuals thereafter might not in fact entertain any actual expectation of privacy regarding their homes, paper, and effects. Similarly, if a refugee from a totalitarian country, unaware of this nation's traditions, erroneously assumed that police were continuously monitoring his telephone conversations, a subjective expectation of privacy regarding the contents of his calls might be lacking as well.

Id. at 741 n.5. Accordingly, the Court suggested that a normative inquiry might be advisable. The Court explained that "where an individual's subjective expectations had been 'conditioned' by influences alien to well-recognized Fourth Amendment freedoms, those subjective expectations obviously could play no meaningful role in ascertaining what the scope of Fourth Amendment protection was." Id. See also Taslitz, Informed Citizen, supra note 44, at 738-56 (discussing the close connection between search and seizure and free speech values).

105. 460 U.S. 276 (1983).

106. Id. at 279 .

107. Id. at 281 . 
a reasonable expectation of privacy in that cabin, no such expectation extended to the automobile's movements or to the movements of the chloroform container outside the cabin in the open fields. Moreover, the beeper did not alter the analysis: "Nothing in the Fourth Amendment prohibited the police from augmenting the sensory faculties bestowed upon them at birth with such enhancements as science and technology afforded them in this case."108 "We have never," concluded the Court, "equated police efficiency with unconstitutionality, and we decline to do so now."109

The Court did place some limits on electronic tracking, however, drawing the line at revelation of actions within a suspect's home. Only a year later, in United States v. Karo, the Court struck down the use of a beeper as too intrusive of privacy interests. ${ }^{110}$ Drug Enforcement Agency agents learned that Karo and others had ordered fifty gallons of ether from a government informant. The ether was said to be used to extract cocaine from a fabric in which it had been transported across national borders. The government obtained a court order authorizing installation and monitoring of a beeper in one of the cans of ether. With the informant's consent, the agents substituted their own can containing a beeper for one of the ten cans in the shipment and had all ten painted to give them a uniform appearance. Agents then watched Karo pick up the cans from the informant and used the beeper to monitor the ether's location. The agents eventually used the beeper to monitor the ether's presence in a house while they obtained a search warrant for the house. The fruits of the warrant search included cocaine and drug manufacturing equipment. ${ }^{111}$

The Supreme Court agreed with the lower courts that the beeper use had gone too far. The beeper had been used to reveal activities inside a private residence, a location not open to visual surveillance. That use invaded reasonable privacy expectations, because, even though visual surveillance was possible up to entry into the house, the beeper enabled the police to determine what they otherwise could not have known-that the article remained in the house during the period in which the warrant was being obtained. Therefore, the monitoring constituted a search. ${ }^{112}$

The Court's line-drawing against electronic surveillance at the door of the home is addressed by the Oregon Supreme Court's decision in State v. Campbell. $^{113}$ The Oregon court pointedly rejected the Katz analysis, adopting an explicitly normative test more sensitive than is Katz to the affective and political

108. Id. at 282 .

109. Id. at 284 .

110. 468 U.S. 705, 716 (1984).

111. Id. at 710 .

112. Unlike the lower courts, the United States Supreme Court found no violation of Fourth Amendment rights in the installation of the beeper, because the defendants had no reasonable expectation of privacy in the can while it belonged to the DEA. The informant owned and possessed the original ten cans, but the can substitution was done with his consent. Finally, no Fourth Amendment rights were implicated when the informant transferred the can to the defendants, because that transfer did not convey private information to the government. Id. at 711-13.

113. 759 P.2d 1040 (Or. 1988). 
functions of privacy: “[T]he privacy protected by ... [the Oregon constitution] is not the privacy that one reasonably expects but the privacy to which one has a right. ..." Moreover, the Court rejected the notion that "information legitimately available through one means [for example, visual surveillance] may be obtained through any other means without engaging in a search." 115 The court concluded that Oregon's constitution protects the people's "interest in freedom from particular forms of scrutiny." 116 That interest extended to surveillance by a radio transmitter:

As we noted above, use of a radio transmitter to locate an object to which the transmitter is attached cannot be equated with visual tracking. Any device that enables the police quickly to locate a person or object anywhere within a forty-mile radius, day or night, over a period of several days, is a significant limitation on freedom from scrutiny, as the facts of this case demonstrate. The limitation is made more substantial by the fact that the radio transmitter is much more difficult to detect than would-be observers who must rely upon the sense of sight. Without an ongoing, meticulous examination of one's possessions, one can never be sure that one's location is not being monitored by means of a radio transmitter. Thus, individuals must more readily assume that they are the objects of government scrutiny.

But if the State's position in this case is correct, no movement, no location and no conversation in a "public place" would in any measure be secure from the prying of the Government. There would in addition be no ready means for individuals to ascertain when they were being scrutinized and when they were not. That is nothing short of a staggering limitation upon personal freedom. ${ }^{11}$

\section{Enhanced Sight into the Home}

In Kyllo v. United States, the Supreme Court held that a Fourth Amendment search had occurred when federal agents employed a device "that is not in general public use" in order to "explore details of [a] home that would previously have been unknowable without physical intrusion." 118 Federal agents received a tip that Kyllo was growing marijuana inside of his home, an operation that typically requires high-intensity lamps. A review of Kyllo's utility bills suggested that his electrical needs were unusually high. The agents then employed a "thermal imager" to scan Kyllo's home for infrared radiation emanating from the roof. ${ }^{119}$ The thermal imager suggested that certain parts of the home were generating more heat than other parts and more heat than surrounding homes. Based on that finding, as well as on the tips and utility bills, the agents obtained a search warrant and discovered a marijuana-growing operation.

Kyllo moved to suppress the fruits of the search warrant, arguing that use of the thermal imager constituted a search. Because the agents did not have a

114. Id. at 1044 .

115. Id. at 1045 .

116. Id. at 1047 (emphasis added).

117. Id. at 1048-49.

118. 121 S. Ct. 2038, 2046 (2001).

119. For a pre-Kyllo explanation and analysis of thermal imaging, see Calnan \& Taslitz, supra note 18 , at $199-208$. 
warrant to use the thermal imager, he argued, the search was illegal. Although lower courts ultimately denied his claim, the Supreme Court agreed.

Central to the Court's reasoning was that the thermal imager revealed information concerning activities inside the home. "We have said that the Fourth Amendment draws 'a firm line at the entrance to the house," ${ }^{120}$ the Court explained. "That line," the Court continued, "must be not only firm but also bright." ${ }^{121}$ Accordingly, the Court rejected the argument that no search occurred because heat is not, and does not reveal, an "intimate detail":

[The government] points out that in Dow Chemical we observed that enhanced aerial photography did not reveal any "intimate details." [citations omitted]. Dow Chemical, however, involved enhanced aerial photography of an industrial complex, which does not share the Fourth Amendment sanctity of the home. The Fourth Amendment's protection of the home has never been tied to measurement of the quality or quantity of information obtained. In Silverman, for example, we made clear that any physical invasion of the structure of the home, "by even a fraction of an inch," was too much ..., and there is certainly no exception to the warrant requirement for the officer who barely cracks open the front door and sees nothing but the nonintimate rug on the vestibule floor. In the home, our cases show, all details are intimate details, because the entire area is safe from prying government eyes. ${ }^{122}$

"At the very core of the Fourth Amendment 'stands the right of a man to retreat into his home." ${ }^{123}$ Although privacy expectations in other settings are unclear, recounted the Court, privacy protection for the home is unambiguous; it is the minimal protection below which the Court cannot go. ${ }^{124}$ "To withdraw

120. 121 S. Ct. at 2046 (quoting Payton v. New York, 445 U.S. 573, 590 (1980)).

121. Id. at 2049.

122. Id. at 2045. In Dow Chemical Co. v. United States, mentioned by the Kyllo majority, the Court reasoned:

Here, EPA was not employing some unique sensory device that, for example, could penetrate the walls of buildings and record conversations in Dow's plants, offices, or laboratories, but rather a conventional, albeit precise commercial camera commonly used in mapmaking. ... It may well be, as the Government concedes, that surveillance of private property by using highly sophisticated surveillance equipment not generally available to the public, such as satellite technology, might be constitutionally proscribed absent a warrant. But the photographs here are not so revealing of intimate details as to raise constitutional concerns.

Dow Chemical Co. v. United States, 476 U.S. 227, 238 (1986). By flatly defining all activities within the home as "intimate," the Kyllo Court avoided any inconsistency with Dow Chemical. At the same time, this excerpted Dow Chemical language supports the Court's idea that privacy protection erodes when technological surveillance becomes widespread, as discussed infra in the text accompanying notes 289326. The Kyllo Court also distinguished California v. Ciraolo, 476 U.S. 207 (1986), upholding aerial surveillance of a house's curtilage under the facts before the Court but conceding that such surveillance could become " invasive" if "modern technology" revealed "those intimate associations, objects, or activities otherwise imperceptible to police or fellow citizens." Id. at 215 n.3 (quoting brief of the State of California). The Kyllo Court characterized this language in Ciraolo as "second-hand dictum [that] was not [based] upon intimacy but upon otherwise-imperceptibility, which is precisely the principle we vindicated today." Kyllo, 121 S.Ct. at 2045.

123. Id. at 2041 (quoting Silverman v. United States, 365 U.S. 505, 511 (1961)).

124. See id. at 2042-43. The Court has elsewhere repeatedly evoked romantic imagery to justify heightened protection for the home. See, e.g., Payton v. New York, 445 U.S. 573, 601 n.54 (1980) (quoting William Pitt's speech before Parliament: "The poorest man may, in his cottage, bid defiance to all the forces of the Crown. It may be frail; its roof may shake; the wind may blow through it, the storm may enter; but the King of England may not enter; all his force dare not cross the threshold of the ruined tenement."); Welsh v. Wisconsin, 466 U.S. 740, 750 (1984) (evoking similar language that the home is a sanctuary). 
protection of this minimum expectation would be to permit police technology to erode the privacy guaranteed by the Fourth Amendment., ${ }^{125}$ History protected that minimum, for, in the Court's view, its task was to assure "preservation of that degree of privacy against government that existed when the Fourth Amendment was adopted." 126 To achieve that assurance, the Court crafted this rule: Sense-enhancing technology that reveals any information regarding the interior of the home constitutes a search, "at least where (as here) the technology in question is not in general public use." "127

This last qualification reveals that the "bright-line protection" that the Court demanded for the home is dimmer than it at first appears. The Court admitted:

[i]t would be foolish to contend that the degree of privacy secured to citizens by the Fourth Amendment has been entirely unaffected by the advance of technology. For example, ... the technology enabling human flight has exposed to public view (and hence, we have said, to official observation) uncovered portions of the house and its curtilage that once were private.

Though the Court next explained that the question before it was "what limits there are upon the power of this technology to shrink the realm of guaranteed privacy," 129 those limits apparently dissolve if technology attains widespread use that significantly raises the probability of detection. Indeed, the dissent, which would have permitted the use of the thermal imager against Kyllo, nevertheless objected to the majority's widespread use qualification precisely on the ground that it offered inadequate long-term protections against the advance of technology. ${ }^{130}$ The Court responded:

The dissent argues that we have injected potential uncertainty into the constitutional analysis by noting that whether or not the technology is in general public use may be a factor... That quarrel, however, is not with us but with this Court's precedent. See Ciraolo, 476 U.S. 207, 215 (1986) ("In an age where private and commercial flight in the public airways is routine, it is unreasonable for respondent to expect that his marijuana plants were constitutionally protected from being observed with the naked eye from an altitude of 1,000 feet."). Given that we can confidently say that thermal imaging is not "routine," we decline in this case to reexamine that factor.

125. Kyllo, 121 S. Ct. at 2043.

126. Id. at 2043.

127. Id.

128. Id.

129. Id.

130. Id. at 2047 (Stevens, J., dissenting). Justice Stevens' dissent was joined by Chief Justice Rehnquist and Justices O'Connor and Kennedy. Stevens' opinion made a distinction between "through-the-wall surveillance," which gives "the observer ... direct access to information in a private area" and "the thought processes used to draw inferences from information in the public domain." Id. at 2047. Stevens saw the dissipating heat as fitting the latter category, for example, because "the ordinary use of the senses might enable a neighbor or passerby to notice the heat emanating from a building, particularly if it is vented, as was the case here." Id. at 2048. The details of Stevens' opinion do not matter for my purposes here because Stevens, like the majority, focuses on cognitive risk-assessment more than rational affective experiences as the standard for judging the existence and scope of privacy protection.

131. Id. at 2046 n.6. 
Strictly speaking, the Court reserved its judgment of whether there would be protection in the home against more widespread technologies of surveillance. As the Court notes, its widespread use qualification is consistent with its precedent and its doctrinal embrace of a probabilities assessment or risk analysis as the determinative factor in defining the scope of privacy protections. The Court ignored the reality that there were stronger affective reasons to support its decision, reasons that might also justify protection outside the home, which will be discussed shortly. ${ }^{132}$

\section{Cross-Currents}

I make no pretense in this article of thoroughly surveying all the United States Supreme Court's Fourth Amendment privacy cases or even all those arguably relevant to technology. Instead, I have focused on the Court's leading technology cases to address those cases' affective blindness. It is important, however, briefly to note subtle counter-currents elsewhere in the Court's Fourth Amendment privacy jurisprudence. I will use the Court's recent decision in Bond v. United States ${ }^{133}$ as my primary example.

In Bond, a Texas Border Patrol Agent boarded a Greyhound passenger bus en route to Little Rock, Arkansas to check the immigration status of the bus passengers. While walking the bus's center aisle, the agent squeezed soft luggage stowed by passengers in the overhead storage bins above their seats. When the agent squeezed a green canvas bag above Bond's seat, the agent felt a "brick-like" object. Bond admitted that the bag was his and agreed to follow the agent to open it. When the agent did so, he found a "brick" of methamphetamine. ${ }^{134}$

Bond was subsequently indicted for conspiracy to possess, and possession with intent to distribute, methamphetamine. He was convicted on both counts after his suppression motion was denied. The Court of Appeals affirmed that

132. Affective reasons would focus on the impact of heat surveillance of the home on individual and group identity; the pressure to conform; the ability to form human relationships without fear of outside observers; and the impact of awareness of governmental scrutiny on the character of the American people, not on the size of the risk being observed. See infra text Part III. The Court seemed a bit more sensitive (at least implicitly) to affective concerns in the home in Wilson v. Layne, 526 U.S. 603 (1999). There, the Court invalidated media presence during the execution of an arrest warrant in a home. The media crews there and in a companion case, Hanlon v. Berger, 526 U.S. 808 (1999) (involving a search warrant), captured on film scenes of the warrant execution, including some that were embarrassing to the homeowners. For example, in Wilson, the Wilsons were filmed coming out of their bedroom in sleeping attire. Although the Court relied on the media's presence as being beyond the scope of the warrant and not aiding any legitimate law enforcement purpose, the Court stressed the special sanctity of the home as central to its decision. See 526 U.S. at 609-12. What is most interesting about the case is that an intrusion on the Wilsons' privacy had already justifiably taken place, namely the entry of the police into their home pursuant to a valid warrant. Yet who else observed (that is, the media), for what purposes, and under what circumstances, mattered in determining the scope of privacy protection. More than the mere risk of observation by anyone was thus determinative, an observation more consistent with an affective than with a cognitive approach to privacy.

133. 529 U.S. 334 (2000).

134. Id. at 336 . 
denial on the ground that squeezing the bag was not a search. The Supreme Court reversed. ${ }^{135}$

The government had argued that Bond lost a reasonable expectation that his bag would not be physically manipulated when he placed the bag in the overhead bin. Relying on the reasoning of Ciraolo $^{136}$ and Florida v. Riley, ${ }^{137}$ the government argued that "matters open to public observation are not protected by the Fourth Amendment." 138

The Supreme Court rejected the broad principle and the analogy:

But Ciraolo and Riley are different from this case because they involved only visual, as opposed to tactile, observation. Physically invasive inspection is simply more intrusive than purely visual inspection. For example, in Terry v. Ohio, 392 U.S. 1, 17-18, we stated that a "careful [tactile] exploration of the outer surfaces of a person's clothing all over his or her body" is a "serious intrusion upon the sanctity of the person, which may inflict great indignity and arouse strong resentment and is not to be undertaken lightly." Although Agent Cantu did not "frisk" petitioner's person, he did conduct a probing tactile examination of petitioner's carry-on luggage. Obviously, petitioner's bag was not part of his person. But travelers are particularly concerned about their carry-on luggage; they generally use it to transport personal items that, for whatever reason, they prefer to keep close at hand.

Here, petitioner concedes that, by placing his bag in the overhead compartment, he could expect that it would be exposed to certain kinds of touching and handling. But petitioner argues that Agent Cantu's physical manipulation of his luggage "far exceeded the casual contact [petitioner] could have expected from other passengers."139

The Court apparently agreed with Bond, concluding first that placing an opaque bag directly above his seat demonstrated a subjective expectation of privacy, and, second, that this expectation was reasonable because, while a bus passenger clearly expects that "other passengers or bus employees may move [his bag] ... for one reason or another," ${ }^{140}$ he "does not expect that other passengers or bus employees will, as a matter of course, feel the bag in an exploratory manner." ${ }^{141}$

The Bond opinion has potential implications for technological privacy jurisprudence in several ways. First, the distinction between visual and tactile observation is made on the ground of affective differences between the two kinds of searches, differences in the extent of "indignation" and "resentment" believed to result from each respective technique. Second, the Court recognizes that the manner of a search matters; expecting some sort of privacy invasion does not mean expecting all. These two points suggest that the Court could be persuaded that some means of technologically-enhanced visual observation out-

135. $I d$

136. 476 U.S. 207 (1986) (no privacy expectations against observation of a backyard from a plane).

137. 488 U.S. 445 (1989) (observation of a greenhouse in a home's curtilage from a helicopter did not violate the Fourth Amendment).

138. Bond, 529 U.S. at 337.

139. Id. at 337-38.

140. Id. at 338 .

141. Id. 
side the home may be at least as insulting and painful as extensive tactile manipulation of luggage. ${ }^{142}$

Third, the Court apparently rejects the idea that the size of the risk of manipulation is primarily what matters. Obviously, other passengers and bus employees had the opportunity to squeeze the luggage and might even feel the brick in the simple process of moving the bag. Though the Court denies that the risk was significant, a more normative analysis is likely at work, as an imminent comparison to the dissenting opinion will reveal.

Fourth, the Court implicitly recognizes that who does the squeezing (searching) matters. If the Court was correct that the sort of manipulation done by the agent here was unlikely (something I by no means concede), that is because police are more likely to engage in bag-squeezing than are other bus passengers and employees. They are more likely to squeeze because they touch the bags with different goals. Furthermore, while a displeased glance might discourage bus passengers and employees from moving or manipulating one's bag, dirty looks will not deter the police. ${ }^{143}$ This distinction suggests that police technological surveillance outside the home is sometimes more invasive than similar surveillance by private persons.

These four observations led Justice Breyer, joined by Justice Scalia, to dissent. ${ }^{144}$ Justice Breyer focused almost entirely on the size of the risk of manipulation. He explained:

How does the "squeezing" just described differ from the treatment overhead luggage is likely to receive from strangers in a world of travel that is somewhat less gentle than it used to be? I think not at all. The trial court, which heard the evidence, saw nothing unusual, unforeseeable, or special about this agent's squeeze. It found that Agent Cantu simply "felt the outside of Bond's soft side green cloth bag," and it viewed the agent's activity as "minimally intrusive touching." The Court of Appeals also noted that, "because passengers often handle and manipulate other passengers' luggage," the substantially similar tactile inspection here was entirely "foreseeable."145

Justice Breyer was unpersuaded by the majority's effort to distinguish this case from Ciraolo and Riley because the "comparative likelihood that strangers will give bags in an overhead compartment a hard squeeze would seem far greater" ${ }^{\prime 146}$ than the risk of being observed in fenced-in property from an aircraft. So long as the officer observed only what "[a]ny member of the public . . could have used his senses to detect," ${ }^{147}$ no invasion of a reasonable privacy expectation was involved. Justice Breyer thus ignored emotional differences and the manner in which the searches were conducted as distinguishing earlier visual inspections from the tactile one before the Court. ${ }^{148}$

142. See infra Part III (exploring the emotional harms of technologically-enhanced video surveillance).

143. See infra Part III.C (examining norms of looking and sanctions for violation).

144. 529 U.S. at 339 (Breyer, J., dissenting).

145. Id. at 340 .

146. Id. at 341 .

147. $I d$.

148. Breyer added: 
Justice Breyer also worried that the majority was redefining privacy as being different where it works to exclude "strangers who work for the Government." ${ }^{149}$ Privacy excludes all "uninvited strangers."150 To hold otherwise, Breyer declared, makes the question of whether privacy has been invaded turn on the actor's purpose rather than his action's effects. Thus a fellow passenger moving your luggage to make more room for his own invades no rights, but a police officer doing so to search for drugs requires constitutional regulation:

Hence, a Fourth Amendment rule that turns on purpose could prevent police alone from intruding where other strangers freely tread. And the added privacy protection achieved by such an approach would not justify the harm worked to law enforcement—at least that is what this Court's previous cases suggest. ${ }^{151}$

Justice Breyer flatly describes the majority's reasoning as departing "from established legal principles," 152 a task that "we should not begin here."153 $\mathrm{He}$ somewhat sarcastically adds that the majority's decision does nothing to protect "true privacy" 154 because nongovernment pokings and proddings of luggage will still occur. Thus he cautions travelers seeking true privacy in luggage contents "to pack those contents in a suitcase with hard sides." 155

Other cases and opinions also suggest counter-currents, ${ }^{156}$ but their timeconsuming analysis would add little to the points I have made with Bond. I do not think that Bond presages any imminent radical shift in the Court's Fourth Amendment privacy jurisprudence, but it appears that Justice Breyer was correct to say that Bond departed from earlier precedent. The Court does sometimes, apparently for very situationally specific reasons, shift privacy analyses from a probability assessment (combined with a normative one heavily weighing the state's crime control needs) to an affective assessment (combined with a normative focus on how to weigh the emotional harms suffered by the affected

Nor can I accept the majority's effort to distinguish "tactile" from "visual" interventions, even assuming that distinction matters here. Whether tactile manipulation (say, of the exterior of luggage) is more intrusive or less intrusive than visual observation (say, through a lighted window) necessarily depends on the particular circumstances.

$I d$. at 342. This passage is ambiguous. Breyer could be saying that "particular circumstances" refers to the probability of detection, a reading most consistent with the content and tenor of the rest of his opinion. On the other hand, this passage also suggests that sometimes visual observation alone might be improper, though his example (the lighted window) seems to do nothing more than pay the usual solicitude toward activities in the home. In any event, Breyer seems to eschew the affective nature of the majority's analysis.

149. Id. at 340 .

150. $I d$.

151. Id. at 342 .

152. Id.

153. Id.

154. Id. at 343 .

155. Id.

156. See generally Andrew E. Taslitz, A Feminist Fourth Amendment: Consent, Care, Privacy, and Justice in Ferguson v. City of Charleston, _ DUKE J. GENDER L. \& POL'Y _ _ (forthcoming 2002) [hereinafter Feminist Fourth Amendment] (arguing that the Court's decision in Ferguson v. City of Charleston, 532 US. 67 (2001), adopted an affective view of privacy that partly turned on the importance of certain human relationships of trust, such as that between doctor and patient). 
individuals). ${ }^{157}$ That willingness at least suggests that the Court may, over the long haul, be not entirely impervious to the alternative, affective conception of privacy to which I now turn.

III

\section{RECONCEPTUALIZING PRIVACY}

The Court's technological privacy jurisprudence suffers from several flaws. All of these flaws stem from the Court's misconception of privacy.

To the Court, what is said or done in "public" is by definition not "private." 158 Thus law enforcement's extended tracking of a car by means of an electronic beeper violated no privacy interest at all. Given the high risk of being observed by passersby, the Court seemed to say, each driver or pedestrian should reasonably expect even longer and more intense observation by the police as well. ${ }^{159}$ This risk analysis is counterintuitive. As Professor William Stuntz has explained, even ordinary, nontechnological stakeouts "sometimes do involve monitoring the movements of a given suspect or all who deal with him over an extended period of time." ${ }^{160}$ That, Stuntz explains, is "roughly the equivalent of being stalked."161

Additionally, the Court has an unduly stingy notion of when "private" information becomes "public." In the Court's view, albeit with rare exceptions, the disclosure of any information to another-even including the finances that you reveal to your bank teller during a business transaction-exposes you to the risk of wider revelation. ${ }^{162}$ The Court likely makes exceptions for confidential disclosures, such as those made by a patient to her doctor. ${ }^{163}$ That a disclosure is made during a relationship of trust, however, probably does not by itself free one from the risk of further disclosure. ${ }^{164}$

157. Thus, again, in Ferguson, 532 U.S. 67, the Court linked privacy and consent issues in determining the reasonableness of a drug-testing program for poor women in a public hospital. A positive test outcome resulted in an ultimatum to the women: Attend a drug counseling program, miss no appointments, and never test "dirty" again, or face criminal prosecution. The Court sharply criticized the program, remanding for proceedings consistent with its opinion. Most importantly, the Court (at least implicitly) considered the breach of trust in the doctor-patient relationship, the informational and other power disparities between the women and their treating physicians, and the symbolic insult to the women's value as equal citizens as central to making these searches ordinary criminal ones likely to be unreasonable (depending upon the factfinding results on remand) under the Fourth Amendment. See generally Taslitz, Feminist Fourth Amendment, supra note 156.

158. See supra Part II (discussing technological privacy case law). I think that this generalization is fair, despite my acknowledgement that there are subtle and modest cross-currents in the case law. See supra text accompanying notes 133-56.

159. See supra text accompanying notes $97-112$ (analyzing case law).

160. Stuntz, supra note 36, at 1277.

161. Id.

162. See supra text accompanying notes 56-104 (discussing "assumption of risk" cases, including the Miller case on banking information).

163. See supra notes 156-56 (discussing the Ferguson case and doctor-patient confidentiality).

164. See supra text accompanying notes 70-104 (summarizing the Court's position that one generally "assumes the risk" of disclosure when one reveals information relevant to alleged crimes to a trusted (albeit, misplaced) cohort in criminality); supra notes 156-156 (mere existence of doctor-patient rela- 
This stingy definition of "private" information relies on a primarily cognitively driven conception of privacy. If a person is or should be aware of a high probability that revelation of information to one person entails revelation to other persons, then the disclosing party no longer has a reasonable expectation of privacy in the data. ${ }^{165}$ However, probability 'assessment is not the end-all of the analysis. The Court at times does consider the emotional impact of privacy invasion, but, absent special circumstances, emotions are almost always subordinated to risk. ${ }^{166}$ Part of the inquiry is normative as well, but the values stressed by the Court usually concern the state's need for the search rather than the individual's need for privacy. ${ }^{167}$ The Court provides for protection of activities in the home, but this too seems to depend significantly on risk analysis. ${ }^{168}$

Moreover, the Court's precedent generally ignores or minimizes the impact of a search or seizure on broader social groups. That the absence of constitutional protection may in practice lead to more "searches" of racial minorities, for example, rarely appears on the Court's radar screen or shows up only as an evanescent blip. ${ }^{169}$

The implications for growing state surveillance into our lives are unattractive. If the means to surveil electronically the inside of the home become more widespread, then police viewing of our intimate activities may be possible without a warrant or reasonable suspicion. ${ }^{170}$ If tracking devices that monitor our movements on the street-in cars, on foot, in stores, or at ATMs-improve, then so does the likelihood of secret police monitoring of our lives. ${ }^{171}$ Our growing use of e-mail, the Internet, and online banking might expand the risk of government access to personal information. ${ }^{172}$ To be sure, political forces may eventually curb the worst abuses, but too many insulting personal invasions may happen along the way, and those with reduced political power may never gain protection against them. ${ }^{173}$

tionship does not alone automatically render a doctor in a state hospital revealing such information to the police an unreasonable search).

165. See supra Part II (analyzing cases).

166. See id.

167. See supra Parts I, II.

168. See supra text accompanying notes 118-31 (discussing the absence of widespread use of a thermal detector as one basis for treating an incident of detector usage as a search in the Kyllo case).

169. See, e.g., Taslitz, Respect, supra note 31; Taslitz, American Passions, supra note 26; Taslitz, Stories, supra note 145 . Dissenting opinions do, however, sometimes see more clearly, giving group impact significant weight. See, e.g., Illinois v. Wardlow, 528 U.S. 119, 129-39 (2000) (Stevens, J., dissenting) (considering African-American attitudes toward, and treatment by, the police relevant to determining the weight to be given to an African-American male's flight from the police in determining whether reasonable suspicion existed). See also Taslitz, Stories, supra note 35, at 30-34 (analyzing Wardlow majority and dissenting opinions).

170. Kyllo, 121 S. Ct. at 2047-48 (Stevens, J., dissenting) (making a similar point).

171. See supra text accompanying notes 289-326.

172. See generally BRIN, supra note 36 , at 32-80; REGINALD WHITAKER, THE END OF PRIVACY: How Total SuRVEILlANCE IS BECOMING A REALITY (1999); Slobogin, supra note 48, at 385-86.

173. See, e.g., William Stuntz, Implicit Bargains, Government Power, and the Fourth Amendment, 44 STAN. L. REV. 553, 588-90 (1992) [hereinafter Implicit Bargains]. Professor Stuntz argues that Fourth Amendment protections crafted by the judiciary are unnecessary where large numbers of affected parties are involved. See id. at 588. Such protection is not needed because affected groups will band to- 
Privacy is, however, more a matter of affect than cognition. Privacy is a set of metaphorical boundaries that enables each of us to safeguard a sense of self. Privacy enables us to decide which aspects of ourselves to reveal and to whom. That control matters deeply, because overly selective exposure of ourselves to others will lead to their misjudging our nature. ${ }^{174}$ Complete revelation of ourselves requires time and trust, and is reserved only for our most intimate relationships. To invade privacy is to unsettle our very identity, distorting relationships with others, self-esteem, and self-concept. ${ }^{175}$ When more of our nature than we wish is exposed to audiences not of our choosing, privacy is lost. ${ }^{176}$ It is therefore possible to be "private" in "public" and to retain information control in the face of partial disclosure. ${ }^{177}$

Because so much of one's sense of self is linked to salient social groups, invasion of an individual's privacy can, under certain circumstances, unsettle group identity as well. The group views assaults on its individual members' sanctity as a forced and partial disclosure of group identity, exposing the group to others' misjudgments of the group's nature. ${ }^{178}$

This section begins by examining the multi-masked sense of self that underlies this notion of privacy, and turns next to explaining how privacy preserves personhood by protecting us from the risk of being misjudged by others. Thereafter, this section examines the risk posed to group identity by privacy invasion, exploring two groups-gays and the "disreputable poor"-as examples, and examining along the way how technological advances could set back gains for these groups. Next, this section examines, in more detail, first why it is important to recognize that activities on the street or in nonsecluded areas can be private; and, second, why the "assumption of risk" doctrine for partial information disclosures is invasive of the self. ${ }^{179}$ Those discussions, by emphasizing the

gether in the political process to correct abuses. See id. at 589-90. For example, Stuntz argues that the Court should not invalidate drunk-driving roadblocks, because the political fury of the many potentially affected drivers will shut down abusive behaviors. See id. at 588-90. Yet Stuntz concedes that "some groups can protect themselves better [by using the political process] than [can] others; as is true elsewhere in constitutional law, judicial review must be preserved where there is a high likelihood of discrimination." Id. at 589. But in this respect, Stuntz also thinks primarily in terms of the total social cost of searches of a specified likely frequency, rather than equally emphasizing the costs to the individuals involved. Political processes can be slow, and many will be hurt while the process gears up to pressure police to halt abuses. See supra text accompanying notes 223-87 (examining the fate of homosexuals subjected to oppressive searches as a group, a problem that did not begin seriously to correct itself for many years, and the fate of the "disreputable poor," who continue their long history of exposure to unjustified searches).

174. See infra Parts III.A-C (defining privacy and its functions).

175. See infra text accompanying notes $175-222$ (privacy and intimacy, and privacy invasions as wounding the sense of self).

176. See infra text accompanying notes 200-222 (explaining the ill effects of privacy invasion).

177. See infra Parts III.D-E (discussing privacy in public versus privacy as information control).

178. See infra Part III.B (on group privacy); Andrew E. Taslitz, Condemning the Racist Personality: Why the Critics of Hate Crimes Legislation Are Wrong, 40 B.C. L. REV. 739, 758-65 (1999) [hereinafter Racist Personality] (discussing the connection between harm to individuals and to their socially salient groups and vice-versa).

179. For an explanation of the assumption of risk doctrine, see TASLITZ \& PARIS, supra note 27, at $109-65$. 
affective centrality of privacy to self-definition, seek to demonstrate that the Court's alternative, predominantly cognitive definition undervalues the private arena in a way that too readily allows technological advances to mean individual and community retreats.

\section{A. Privacy as Self-Definition}

1. The Many Masks of the "Self." Any sound conception of privacy must begin with a conception of personhood, of the "self." Both common experience and psychological research reveal that the "self" is a multiple, rather than unitary, concept. ${ }^{180}$ Psychologist Walter Mischel explains, albeit in somewhat different language, that different aspects of our character or personality-our propensities to think and act in certain ways-are called forth by different situations. ${ }^{181}$ We may be tardy when attending parties but punctual when attending church. We may be rude under time pressure, but otherwise civil and kind. We wear one mask at a ball game, and another at work. ${ }^{182}$

No single one of these masks is inauthentic. ${ }^{183}$ Each reflects one aspect of our nature. The totality of who each of us believes we really are consists, however, not of any one of these masks but of all of them together. ${ }^{184}$ We often do not want to be judged, for example, as "cruel" by someone who has not seen us be kind. Since it takes time for another to achieve "true knowledge" of our nature, we are vulnerable to their misjudgments during the long period when only some aspects of our selves are slowly being revealed. ${ }^{185}$ We therefore reserve such total revelation for a small circle of intimates, and, partly because of its rarity, this revelation in turn becomes a symbol of, and a process for, achieving personal closeness. ${ }^{186}$ Correspondingly, safety from the misjudgments of nonintimates requires protection from their gaze. Professor Jeffrey Rosen explains:

True knowledge of another person ... requires the gradual setting aside of social masks, the incremental building of trust, which leads to the exchange of personal dis-

180. See, e.g., Andrew E. Taslitz, A Feminist Approach to Social Scientific Evidence: Foundations, 5 Mich. J. GENDER \& L. 1, 12-25 (1998) [hereinafter Feminist Approach] (discussing the social and interpretive nature of the self); Andrew E. Taslitz, Myself Alone: Individualizing Justice Through Psychological Character Evidence, 52 MD. L. REV. 1, 31-34, 64-72 (1993) [hereinafter Myself Alone] (asserting that character and personality are more situationally specific than not).

181. See Theodore Millon, Disorders OF PERSONALITY 
closure. It cannot be rushed. ... True knowledge of another person, in all of his or her complexity, can be achieved only with a handful of friends, lovers, or family members. In order to flourish, the intimate relationships on which true knowledge of another person depends need space as well as time: sanctuaries from the gaze of the crowd in which slow mutual self-disclosure is possible. ${ }^{187}$

2. The Fear of Misjudgment. The individual's fear of misjudgment by "the unwanted gaze" of the crowd is fully justified. ${ }^{188}$ People generally employ a "halo effect"- a tendency to judge another's entire nature based on one perceived good trait. ${ }^{189}$ Moreover, such judgments are readily based on little evidence, perhaps by observing a few isolated deeds, which are often taken entirely out of context. ${ }^{190}$ Once these judgments are made, they are hard to change, despite subsequent evidence to the contrary. ${ }^{191}$ A corollary effect, the "devil's-horn effect," is even more powerful; that is, observers are more likely to generalize from past misdeeds that one is a bad person than to generalize from past good deeds that one is a good person. ${ }^{192}$ The part becomes the whole, and the bad drives out the good. ${ }^{193}$ Peter Lewis made this point well in The New York Times:

Surveillance cameras followed the attractive young blond woman through the lobby of the midtown Manhattan hotel, kept a glassy eye on her as she rode the elevator up to the $23^{\text {rd }}$ floor and peered discreetly down the hall as she knocked at the door to my room. I have not seen the videotapes, but I can imagine the digital readout superimposed on the scenes, noting the exact time of the encounter. That would come in handy if someone were to question later why this woman, who is not my wife, was visiting my hotel room during a recent business trip. The cameras later saw us heading off to dinner and to the theater - a middle-aged, married man from Texas with his arm around a pretty East Village woman young enough to be his daughter.

As a matter of fact, she ... [ was] my daughter. ${ }^{194}$

This fear of being misjudged based upon others' observing isolated actions taken out of context may describe why we suppress certain aspects of ourselves in some settings. We may believe that wearing pyramid-shaped hats channels

\section{Id.}

188. Id. at 19-20 (expanding on the "unwanted gaze" of the crowd).

189. Miguel Mendez, California's New Law on Character Evidence: Evidence Code Section 352 and the Impact of Recent Psychological Studies, 31 UCLA L. REV. 1003, 1057 (1984); Taslitz, Myself Alone, supra note 180, at 106-07.

190. Taslitz, Myself Alone, supra note 180, at 107; see generally LEE ROSS \& RICHARD E. NISBETT, The PeRson AND The SituATION: PERSPECTIVES ON Social PSYCHOlOGY (1991).

191. See Mendez, supra note 189, at 1047-50 (character judgments are readily made based upon little evidence and are hard to correct by jury instructions); Taslitz, Myself Alone, supra note 180, at 112 \& nn. 634-35 (people often persevere in character assessments even in the face of evidence of their error, though providing them with the theoretical and empirical explanations both of why they are wrong and why they refuse to accept evidence of their mistake can at least modestly, and sometimes significantly, help them to correct their judgment, a set of curative conditions sometimes present in the courtroom but unlikely to be present in everyday life).

192. See RosEN, supra note 45, at 137-38 (describing Mendez's work and the "devil's horn" effect).

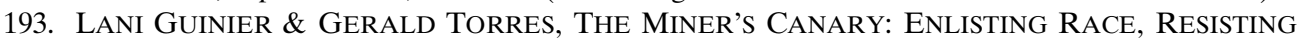
POWER, TRANSFORMING DEMOCRACY 169-71 (2002) (defining synecdoche and its political variant in majoritarian rule: The part (the majority) is taken as representing the whole (the people), thus driving out the real inter-group continuing conversations that best define democracy).

194. Peter Lewis, Forget Big Brother, N.Y. TIMES, Mar. 19, 1998, at G1. 
universal invisible energies into our soul, be sloppy in caring for our personal finances and leisure dress, and spend most of our time at home sleeping and watching television. Yet we may rightly fear that revealing these traits at our job as an investment banker will lead our boss and co-workers to suspect that we are weird, careless, and lazy when, at least on the job, we are none of these things. ${ }^{195}$ Similarly, we would not want word of one mistake that we made at work to be gossiped about at the watercooler, for we fear that the bad will drive out the good, that our previously justly earned reputation as a meticulous employee-the employee we believe we still are, when judged in the totality of all our office actions-will vanish. ${ }^{196}$

Being misdefined causes humiliation, indignity, and mental distress. ${ }^{197}$ "There are," Jeffrey Rosen explains, "few experiences more harrowing than being described: [T] o be described is to be narrowed and simplified and judged out of context." Consequently, "there are few acts more aggressive than describing someone else." 199

3. Privacy as the Solution to the Fear of Being Misjudged. Privacy is the creation of boundaries that protect us against the risk of being misdefined and judged out of context. ${ }^{200}$ Privacy is therefore one way by which we express our need for individualized justice: for being judged for who we really are. ${ }^{201}$ Privacy enables us to define our sense of self so that we experience invasions of privacy as assaults on our identity. ${ }^{202}$ The freedom that privacy gives us to express parts of our identity to select others in certain situations, and all of our identity to a select few, promotes life-enhancing intimate relationships and human autonomy. ${ }^{203}$ We can pursue our own unique interests, learning and doing what we want within broad limits, without the fear of another's gaze. ${ }^{204}$ As one commen-

195. See generally RoSEN, supra note 45, at 8-9 (on the fear of being misjudged).

196. Id. at 8-9 (on the dangers of gossip); JOSEPH TELUSHKIN, WORDS THAT HURT, WORDS THAT HEAL: How TO CHOOSE WORDS WISELY AND WELL 11-66 (1996) (explaining why Jewish law especially condemns spreading negative but accurate information).

197. Rosen, supra note 45, at 21.

198. Id. at 205-06.

199. Id. See also GUINER \& TORRES, supra note 193, at 169-73 (explaining the emotional harms to groups, not merely individuals, from being defined by others in the political process).

200. Rosen, supra note 44 , at 8.

201. Taslitz, Myself Alone, supra note 180, at 24-30 (defining individualized justice); Taslitz, Racist Personality, supra note 178, at 746-58 (elaborating on the meaning and significance of individualized justice).

202. See infra text accompanying notes 327-29 (discussing sociologist Erving Goffman's theory of "territories of the self").

203. See, e.g., Anita Allen, Uneasy Access: Privacy For Women In A Free Society 52 (1987) ("[T]he exercise of privacy-promoting liberties enhance persons and personal relationships in ways that cannot be ignored by those who feel ethically constrained to treat persons as more than things."); ROSEN, supra note 45 , at 8 (discussing how control over which masks we reveal promotes intimate relationships).

204. Patricia Boling, Privacy and the Politics of the Intimate Life 79 (1996). Boling writes:

A third reason to respect the individual's privacy about intimate life-decisions has to do with the need to value and respect diversity. Scrutinizing an individual's intimate practices and 
tator has explained, the root of the right to read anonymously, that is, without others knowing and perhaps disapproving what we read, is not First Amendment free speech alone but Fourth Amendment privacy as well. ${ }^{205}$

Identity is not, however, entirely a matter of individual choice. Identity, and therefore privacy, also has a social aspect. ${ }^{206}$ Identity is social partly because others help to define our character. The moral lessons our parents teach us, the type of childhood games learned from our peers, and the sorts of teachers we had in elementary school all contributed to making us who we uniquely are..$^{207}$

Identity is also social because most individuals have at least some affective ties to salient social groups, ties that each individual views as central to his nature. ${ }^{208}$ Are we Christian or Muslim? Are we Greek-American or ItalianAmerican? Republican or Democrat? The unique combination of each person's group connections is part, though by no means all, of what defines him. ${ }^{209}$

Finally, identity is social because how other people treat us and how we treat them is also constitutive of our nature. ${ }^{210}$ The integrity of individual personality therefore depends upon mutual observance of certain social norms. ${ }^{211}$ Sociologist Erving Goffman explained this in terms of rules of deference and demeanor. "Rules of deference" are the social norms defining the conduct by which one person conveys appreciation to or of a recipient or something of which the recipient is taken as a symbol. ${ }^{212}$ "Rules of demeanor" define the conduct by which each person expresses to those in his immediate presence that he is a person of certain desirable or undesirable qualities. ${ }^{213}$ Taken together, these two types of rules bind actor and recipient together, as well as with society. When we follow these rules, we confirm the social order, simultaneously

demanding conformity to an implicit standard promotes homogeneity and undercuts and devalues differences. Assuming an essentialized identity based on intimate affiliations or decisions likewise renders the diversity of people's experiences invisible, placing normalizing pressure on different or dissenting group members.

Id.; see also generally JUDITH WAGNER DECEW, IN PURSUIT OF PRIVACY: LAW, ETHICS, AND THE RISE OF TECHNOLOGY 66 (1997) (stating that privacy marks a zone of interests beyond the legitimate concerns of others to protect against pressures to conform or to reveal one's vulnerabilities); FERdinAND DAVID SCHOEMAN, PRIVACY AND Social FREEDOM (1992) (asserting that freedom from scrutiny and judgment permits us to talk, think, and act in ways that express our unique individual identity).

205. Rosen, supra note 45 , at 169.

206. Taslitz, Feminist Approach, supra note 180, at 12-25.

207. Id. at $12-25$.

208. Id. at 23; Taslitz, Racist Personality, supra note 178, at 758-65; see also GUINIER \& TORRES, supra note 193, at 49-54, 75-107 (explaining that racial group identity is so salient for many individuals in minority groups that appeal to race can be both personally empowering and a strong motivator for political organizing and agitation).

209. Taslitz, Feminist Approach, supra note 180, at 23.

210. Id. at 12-25.

211. Robert Post, Constitutional Domains: Democracy, COMmunity, Management 54 (1995).

212. Erving Goffman, The Nature of Deference and Demeanor, in INTERACTIONAL RITUAL: ESSAYS ON FACE-TO-FACE BEHAVIOR 47, 56 (1967).

213. Id. at 77 . 
creating "ritual" and "sacred" aspects of our own and others' identities. ${ }^{214}$ These rules are often called the "common rules of civility." 215

When others refuse to follow these rules, they interfere with our freedom to choose a particular social mask, thereby marking us as unworthy of that freedom. ${ }^{216}$ Because these rules define the obligations of each member of society toward one another, violating the rules toward others also identifies the latter as outside of, or at least as not full members of, society. ${ }^{217}$ Breaking the rules of civility thus demeans and excludes the recipients of abuse. Those recipients are entitled to, and generally do, experience affront at such insulting treatment because it treats them as low-status outsiders, discrediting their identity as equal community members and injuring their personality. ${ }^{218}$

It is for this reason that damages awarded for privacy torts are often described as serving the purpose of "vindicating the plaintiff," normally doing so by awarding him both compensatory and punitive damages. ${ }^{219}$ Yet,

[t]o say that the plaintiff in an invasion of privacy suit required vindication, however, is to imply that he is somehow in need of exoneration. But this implication is puzzling, for the plaintiff has been the victim, not the perpetrator, of a transgression. The shame of the victim, however, is made explicable by the fact that he has been denied respect, and consequently his status as a person to whom respect is due has been called into question. ${ }^{220}$

Accordingly, the plaintiff can be vindicated only by an action that reaffirms his membership in the community, demonstrating that he and the offender are of equal worth as citizens and as human beings. Such an action is the very definition of personal retributive justice. ${ }^{221}$ The seemingly excessive damages sometimes characterizing tortious invasions of privacy actions can, therefore, be seen as justifiable acts of reaffirming the plaintiff's worthiness and belongingness. By reaffirming social norms, such damages also help to "reforge" the "chain of ceremony" that binds society together. ${ }^{222}$

Conceiving of privacy as the boundaries protecting our ability to reveal only certain aspects of our selves to particular others alters the probability risk assessment embodied in the Court's Fourth Amendment privacy jurisprudence. Privacy is more about civility, respect, intimacy, and recognition than surviving the struggle to limit life's risks. That focus on affect rather than cognition has

214. Id. at $84-85,90-91$.

215. POST, supra note 211, at 56.

216. Id. at $55-56,59$.

217. See id. at 59 ("The victim of the breach of a civility rule ... has been excluded from the "chain of ceremony' that establishes the respect normally accorded to full-fledged members of the community").

218. Id. at 55-56, 59.

219. RESTATEMENT (SECOND) OF TORTS $§ 901 \mathrm{cmt}$. c (1977).

220. Post, supra note 211, at 59.

221. See Andrew E. Taslitz, The Limits of Civil Society: Law's Complementary Role in Regulating Harmful Speech, 1 MARGINs 305, 313-24, 346-49, 373-76 (2001) [hereinafter Civil Society] (discussing the function of retribution in reaffirming human worth and the distinction between personal and public retributive justice).

222. POST, supra note 211 , at 59. 
broad implications for Fourth Amendment privacy limitations on police use of technology. Before exploring these implications, it is important to recognize, however, that privacy invasion can harm groups as well as individuals.

\section{B. Group Implications}

Privacy inheres in groups as well as individuals. ${ }^{223}$ Indeed, the opportunity for groups to gather in homes, civic centers, schools, and churches-all the time substantially insulated from outsiders' eyes-may be necessary to promoting the free exchange of ideas that define a democracy. ${ }^{224}$ Such an exchange can also encourage group solidarity, enhancing part of each individual's sense of self while emboldening group members eventually to express their views in a broader public forum. ${ }^{225}$ Apart from its role of promoting citizen involvement in political movements, privacy also encourages the diversity and autonomy purportedly valued by liberal states, because privacy frees citizens from the "tyranny of the prevailing opinion and feeling." 226 One commentator made the point thusly:

We all deserve to live in separate communities, or among or within separate normative spaces. Privacy, or the ability to control data about yourself, supports this desire. It enables these multiple communities and disables the power of one dominant community to norm others into oblivion. Think, for example, about a gay man in an intolerant small town. ${ }^{227}$

1. Gay Rights As An Illustration. The experience of the gay community in the mid-to-late twentieth century is indeed a good illustration of these points. Privacy for gays to congregate with one another is essential to developing per-

223. Cf. ALLEN, supra note 203, at 146-47 (recognizing that privacy can inhere in groups and promote important self-development values). Allen cautions, however, that there are costs as well as benefits to recognizing group privacy such that some formerly "private" group activities should now be considered "public":

Should men be allowed realms of private association from which women are excluded?

Should women give men social breathing space free of female attention? I argued that they should, if an important condition is met. Men's social organizations have no just claim to exclude on the basis of sex if they also function as centers of commercial privilege. The mixing of social and economic functions turns innocuous social segregation into real inequality for women.

Id. at 152 .

224. See RoSEN, supra note 45, at 168-69, 182, 196-97, 218-19 (explaining how privacy protects freedom of speech and dissenting and diverse views, while noting that the "right to read anonymously is deeply rooted not only in the First Amendment but also in the constitutional guarantee of freedom from unreasonable searches and seizures").

225. See GUINIER \& TORRES, supra note 193, at 82-107 (explaining that intra-group exchanges can promote solidarity, self-esteem, and group consciousness that motivate political engagement). See also infra text accompanying notes 228-58 (exploring the interaction between growing privacy protection and enhanced gay solidarity).

226. JOHn StUART MiLl, On Liberty 11 (Haldeman-Julius 1925) (1859).

227. Lessig, supra note 37, at 152-53; cf. ERIC A. POSNER, LAW AND SOCIAL NORMS 221 (2000) ("[T]he rule of law and the legal protection of privacy are two arms of a general approach to solving the pathologies of non-legal mechanisms of enforcement... . To minimize the influence of non-legal enforcement ... of [certain oppressive social] norms, the state protects privacy, which deprives the crowd of the information it needs to inflict sanctions."). 
sonal relationships and the group identification central to many gay individuals' identity. ${ }^{228}$ Selective breach of that privacy, however, reveals partial information not only about the individuals involved but also about the gay community as a whole. A heterosexual audience observing isolated aspects of gay life may more deeply accept stereotypes about that community. ${ }^{229}$ The gay rights movement can thus be seen not only as seeking freedom from pressure to conform to majoritarian social norms, but also as a struggle for recognition of the gay community as a legitimate social group with shared rituals and identities, yet whose individual members are complex, unique, and diverse, partly defined by their sexual orientation, but also by a multitude of other factors. ${ }^{230}$

The community and its members seek to be recognized for who they are rather than judged for who they are not. ${ }^{231}$ In short, the gay rights movement sought, and still seeks, respect both for the gay community and for its individual members. ${ }^{232}$

Search and seizure practices were, however, once routinely used to deny the gay community and its members such respect. ${ }^{233}$ During the 1950 s, police spent "hours perched above public toilets, peeking into parked cars, and even following homosexuals and peering through doors into bedrooms." ${ }^{234}$ Raids carried out by police in many cities led to wholesale arrests of "gender ... devi-

228. DAVID A.J. RiCHARDS, IDENTITY AND THE CASE FOR GAY RightS: RACE, GENDER, RELIGION AS ANALOGUES 81-83, 171-201 (1999) [hereinafter IDENTITY AND GAY RIGHTS] (broadly discussing privacy's centrality to the maintenance of gay identity); see generally DAVID A.J. RICHARDS, WOMEN, GAYs, AND THE CONSTITUTION: THE GROUNDS FOR FEMINISM AND GAY Rights IN CULTURE AND LAW (1998) [hereinafter CONSTITUTION].

229. David Richards has explained a similar point this way:

I . . criticize the common view that suspect classifications turn either on the immutability or salience of a trait or on the alleged powerlessness of a group. Rather, on the alternative view I propose and defend, such classifications are suspect because they illegitimately assume as their basis the culturally constructed stereotypes and prejudices that make up moral slavery. Laws grounded on moral slavery not only lack any acceptable basis in the constitutionally required public reasons for all laws of justice and the common good, but work unreason by illegitimately rationalizing its structural injustice. The structure of this account of suspect classification analysis is the condemnation of a basis for law that reflects the degradation of a cultural tradition (moral slavery) with which a person reasonably identifies in terms of their conscientious sense of personal and moral identity.

RICHARDS, IDENTITY AND GAY RIGHTS, supra note 228, at 4.

230. See Taslitz, Racist Personality, supra note 178, at 746-65 (exploring the human needs for both group and individualized justice).

231. See id. at 746-65 (on being judged for who we are); RICHARDS, IDENTITY AND GAY RIGHTS, supra note 228, at 4 (addressing a similar point, but as to the gay community); IRIS MARION YOUNG, INCLUSION AND DEMOCRACY 104-06 (2000) (stating that cultural groups seek recognition of their uniqueness as being of equal status with others, both for the inherent emotional benefits of such recognition and as "part of demands for political inclusion and equal economic opportunity, where the claimants deny that such equality should entail shedding or privatizing their cultural difference").

232. For a detailed explanation of the meaning of "respect," see Taslitz, Respect, supra note 31.

233. For histories of the struggle for gay rights, including search and seizure practices, see PATRICIA Cain, Rainbow Rights (1999); Joyce Murdoch \& Deb Price, Courting Justice: Gay Men AND LESBIANS V. THE SUPREME COURT (2001).

234. William N. Eskridge, JR., GAy LAW: Challenging the APARTheid of the Closet 64 (1999). 
ants." ${ }^{235}$ Arrests were made for disorderly conduct for "same-sex hugging and kissing." ${ }^{236}$ An incident receiving widespread media and political attention often triggered "a frenzy of antihomosexual arrests, detentions, and harassment by police." ${ }^{237}$ Meanwhile, the FBI continued its longstanding practice of surveilling homosexual individuals, organizations, and political activities. ${ }^{238}$ Informants and infiltrators were used widely and aggressively. ${ }^{239}$ Local police used similar tactics, and information was often selectively leaked, in the hope, for example, that monitored homosexuals would then lose their jobs. ${ }^{240}$ Procedural protections against arbitrary searches and seizures did little good. Many of the accused pled guilty rather than face further exposure. They therefore lost any chance even to try to suppress challenged evidence. ${ }^{241}$ Bias among judges also led to weak enforcement of search and seizure laws, making these few rules of procedure less than "highly protective." ${ }^{42}$

The Criminal Procedure Revolution of 1961 to 1969 changed this state of affairs, shifting police investigations from their original focus on cross-dressing, consensual sex, and oral solicitation, to instead punishing same-sex prostitution, sex with minors, and pornography. ${ }^{243}$ The incorporation of the criminal procedure protections of the Bill of Rights against the states led to reversed convictions and discouraged prosecution by raising the costs of proceeding and by assuring homosexuals legal representation. ${ }^{24}$ Offenders who previously would have plea-bargained now vigorously pursued suppression motions. Public toilet surveillance dropped as some courts extended privacy protections to such sites, and even to sex in automobiles and adult theater booths. ${ }^{24}$ The expansion of search and seizure rights led to press attention, and gay groups, with the threat of lawsuits in their hands, organized politically and gained the ear of police ad-

235. Id.

236. Id.

237. Id.

238. Id. at 74. For illustrations of more recent efforts at surveilling homosexuals, see GARY T.

MARX, UNDERCOVER: POLICE SURVEILlANCE IN AMERICA 98, 168, 173 (1988).

239. ESKRIDGE, supra note 234, at 75.

240. Id. at 73-74.

241. Id. at 87.

242. Id. at 88 .

243. For an outstanding, concise history of that revolution, see CRAIG M. BRADLEY, THE FAILURE OF THE CRIMINAl PROCEDURE REVOLUTION xi-36 (1993). Bradley's title can be deceiving. He acknowledges that the Court's revolutionary extension of Bill of Rights criminal procedural protections to the states has significantly increased police respect for constitutional rights, improved police training, largely ended the "third degree," and improved legal representation. Id. at 37. The revolution's failure, he believes, lies in its not achieving clarity and stability. Id. at 37-39. For a discussion specifically reviewing how the revolution affected the gay community, see ESKRIDGE, supra note 234, at 101-11.

244. ESKRIDGE, supra note 234, at 102 . For a quick summary of the incorporation process, see BRADLEY, supra note 243, at 18-34.

245. ESKRIDGE, supra note 234, at 102-03. For arguments that "public" toilet use is protected by privacy rights, see MARK TUNICK, PRACTICES AND PRINCIPLES (1998); Sherry Colb, Qualitative Dimension, supra note 38, at 1708-13 (suggesting that because people value privacy from observation in the restroom, that value should be incorporated into the meaning of Fourth Amendment "reasonableness" when evaluating the legitimacy of law enforcement practices invading toilet facilities). 
ministrators. ${ }^{246}$ Political organizing may have started the process of lowering arrest rates and forcing police to consider gay interests. Expanded search and seizure protections, in turn, meant that "gay politics deployed rights discourse to put the police on the defensive and, gradually, to leverage concessions from the political system." ${ }^{247}$ Fourth Amendment and similar state constitutional protection was only one force among many at work in the gay rights movement. Nevertheless, such protection did play an important contributing role in creating, by the early twenty-first century, a more open, diverse, and vibrant gay culture, accompanied by increasing gay political power. ${ }^{248}$ Gay rights still have a long way to go, but whatever recognition the gay community's members receive today as equal citizens owes much to expanded, albeit imperfect, privacy protections. ${ }^{249}$

The opposite argument-namely, that the existence of group political power means that individual members of that group do not need constitutional protection by the judiciary—carries little weight. Professor Stuntz has suggested this

246. ESKRIDGE, supra note 234, at 103-04.

247. Id. at 104.

248. Eskridge explains:

The details of these stories in individual cities are less important than the general lesson:

$[R]$ ights for gay people accused of consensual sex crimes did not affect arrest rates until gay political power forced police departments to consider their interests. In turn, however, gay politics deployed rights discourse to put the police on the defensive and, gradually, to leverage concessions from the political system. Once an electorate could identify pro-gay candidates such as Hongisto, Pines, and Koch with "law and order," such candidates were electable in big cities.

Id.; see also CAIN, supra note 233 (discussing the history of the gay rights movement).

249. Of course, protection for gay identity requires both "substantive" privacy rights—such as the right to engage in consensual sodomy-and procedural privacy rights—such as expansive protection against police action in various venues absent individualized suspicion. See ESKRIDGE, supra note 234, at 101-08. To argue that substantive privacy rights-which decriminalize much homosexual sexual behavior-matter most is to ignore the special roles that procedural privacy protection can play. First, both courts and legislatures may long be unwilling to accept such decriminalization. Yet our legal culture does not eliminate procedural privacy protections simply because conduct has been criminalized. For example, selling cocaine is a crime, but the police may not willy-nilly knock down doors to homes in a quest for cocaine sales. Individualized suspicion based on trustworthy evidence, and rising to the level of probable cause, is still required. See supra text accompanying notes 123-26 (probable cause and warrant protections are strongest in the home). These protections raise the cost of criminal prosecutions by pressuring the police to conduct more thorough investigations, reducing the chances of harming innocent civilians, and recognizing the value of privacy for human self-determination, even for those believed to be engaged in a criminal enterprise. See supra text accompanying notes 180-223 (discussing privacy and self-determination).

Second, precisely by raising the costs of prosecution, criminal procedural rights shift state resources away from certain crimes toward others, such as drug sales or other crimes that occur on public streets and are thus more easily observable. See Stuntz, Distribution, supra note 35, at 1266-67. Sometimes this cost-shifting has perverse effects, for example, increasing criminal prosecution of the poor, who are more likely than the rich to spend more time on the streets. See id.(making a similar point). But other times, as with much of the gay community, increased procedural privacy rights effectively moved closer to decriminalization of much gay sexual conduct while increasing gay political power. See supra text accompanying notes 228-47. That process may, in turn, one day lead to true decriminalization. But see William J. Stuntz, The Uneasy Relationship Between Criminal Procedure and Criminal Justice, 107 YALE L. J. 1 (1997) (examining the sometimes perverse and unintended consequences of criminal procedure protections on substantive criminal law); William J. Stuntz, Substance, Process, and the Civil Criminal Line, 7 J. CONTEMP. LEGAL IssuEs 1 (1996) (arguing that, absent greater constitutional regulation of legislative choices about what and how to criminalize, criminal procedure protections sometimes create incentives that ultimately worsen the fate of the poor and disempowered). 
argument when explaining why the Court has approved suspicionless drunk driving checkpoints: "The likeliest explanation for giving greater leeway to group stops is that politics provides an adequate remedy for overzealous police action; groups of drivers, unlike the solitary suspect, can protect themselves from overzealous police tactics at the polls."250 However, that does nothing to protect individuals affected in the interim, while the political process waits to work. Moreover, the political process model adopts a majoritarian approach to constitutional rights that nullifies the rights of dissenters. ${ }^{251}$ If certain minimal rights define each individual's humanity, denying those rights to serve community needs-making the community primary, the individual secondary-violates human dignity. ${ }^{252}$ The idea of the individual as "sovereign" is corrupted. ${ }^{253}$ Fur-

250. Stuntz, Implicit Bargains, supra note 173, at 588.

251. See, e.g., Evan Gerstmann, The Constitutional Underclass: Gays, Lesbians, AND THE FAILURE OF CLASS-BASED EQUAL PROTECTION (1999) (explaining why the political process and other justifications for "suspect class" analysis are often used to limit the expansion of suspect class status to "newer" minorities and dissenters while extending protection to political majorities-for example, striking down race-based affirmative action legislation as involving a "suspect classification").

252. Cf. Erik Luna, Sovereignty and Suspicion, 48 DUKE L.J. 787 (1999) (defending the idea of Fourth Amendment rights as residing in the "sovereign individual"). I do not want to suggest that I embrace in wholesale fashion Erik Luna's idea of the "sovereign individual." My own approach to rights-definition is more relational and social than is Luna's; space constraints prevent me from outlining my position at length here, but I have discussed it elsewhere. See Taslitz, Respect, supra note 31. My bottom line, however, is that the communal and social nature of rights permits some rights to be vested in groups or communities but requires most rights to vest either additionally or exclusively in the individual, partly because such protection for the individual is essential to creating and defining a sound conception of community. C $f$. Beth J. Singer, Pragmatism, Rights, AND DemOCRACY (1999) (taking a somewhat similar, though by no means identical, approach to defining rights); ALEXANDER TSEIS, DESTRUCTIVE MESSAGES 211-35 (forthcoming 2002) (asserting that true communitarianism requires rights protection for the individual); Martin P. Golding, Towards a Theory of Human Rights, 52 THE MONIST 521, 528 (Oct. 1, 1968) (taking a different approach while still concluding that "every claim of right makes implicit reference to a community," for outside the social context, "rightsdiscourse has no foothold"). I am, therefore, not arguing that the individual's rights always "trump" the rights or interests of the community. But neither can community rights or needs-especially if by "community" we mean a numerical majority—routinely trump the rights or needs of the individual. The individual's rights should be infringed or restricted only for a pressing need. In this sense, the individual is "sovereign" and, in practical terms, both my approach and one viewing rights as originally rooted in the individual alone are unlikely to lead to different results for the purposes of this article. Indeed, because I embrace a concept of "personhood" that entails certain individual rights, though turning to more social notions of the "person" than do some other theorists, I often see no point in departing from more traditional terminology, hoping that I can convince a wider audience on its terms rather than my own. See, e.g., Taslitz, The Limits of Civil Society, supra note 221 (demonstrating that traditional rights discourse supports protecting both individuals and groups from certain speech-based injuries, at least under particular circumstances). I elaborate on my different approach to rights only where the differences may alter outcomes or serve important communicative functions. See Taslitz, Respect, supra, note 31 (explaining in more detail my vision of the meaning and interpretive sources of rights).

253. See Luna, Sovereignty and Suspicion, supra note 252, at 878-83 (explaining why political process models are unduly deferential to the state in the area of drug-testing and impinge upon individual sovereignty). Professors Lani Guinier and Gerald Torres explain more generally that representation based on majority rule denies minority groups a voice, often discouraging individual group members from banding together to act jointly as a coherent political force. See GUINIER \& TORRES, supra note 193, at 49-55, 170-71. Heightened racial group consciousness can act as a counterweight, promoting enhanced individual self-esteem and group political mobilization. See id. at 86-106. What matters most here about their approach is that it recognizes the importance of group affiliation to individual identity and individual action to group coherence and political power. More importantly, however, they see ra- 
thermore, the theory seems to ensure growing continuing roadblocks to minority group political power. If rights recognition gives minorities a tool to use in navigating politics, then when that tool works - when the group starts gaining political power - the judicially enforced right itself is no longer needed. But ending that right, or at least doing it too early, may erode precisely the political gains that led the Court to declare the right no longer necessary. ${ }^{254}$ Furthermore, a judiciary dominated by a racial, ethnic, or gender majority might too readily see adequate political "progress" where it does not truly exist. On the

cially-conscious minority group politics as ultimately self-defeating if it is understood as but an expression of group self-interest. See id. at 54. Group consciousness is but the first step if group identity is to be used as a basis for progressive reform. See id. The next step must be for groups to move from "their own grievances to articulate a larger social justice critique and [to] organizing relationships democratically to resist both horizontal and vertical hierarchies of power." Id. Guinier and Torres's goal, therefore, is to have a more widely participatory electorate routinely engaged in political struggle and conversation. See id. at 94-98, 213-21. Furthermore, they recognize the importance of individual agency, see id. at 221, while seeing the fates of individuals, groups, and entire political communities as inextricably linked.

Combining these insights with Erik Luna's urging that individual sovereignty be at least a central part of any rights strategy suggests a new way of understanding the text of the Fourth Amendment. That text is commonly understood as vesting rights solely in the individual. See, e.g., Paul Finkelman, "A Well Regulated Militia": The Second Amendment in Historical Perspective, in THE SECOND AMENDMENT: Historians AND CONSTITUTIONAL SCHOlARs ON THE Right TO BEAR ARMS 117, 142 (Carl Bogus ed., 2000). This is so even though the Fourth Amendment expressly declares a "right of the people...." See U.S. Const. Amend. IV.; Finkelman, supra, at 117. The right of the people that the amendment creates, however, is the right to "be secure in their persons, houses, papers, and effects ...." U.S. CONST. Amend. IV. Individuals - not collectivities, own their persons, houses, and effects - so to this extent the individual rights interpretation makes sense. See Sanford Levinson, The Embarrassing Second Amendment, 99 YALE L. J. 637, 645 (1989) (containing an analogous argument). Furthermore, such an interpretation serves as a reminder, as I have argued here, that core rights defining personhood must not be too readily sacrificed to community needs.

But there is not necessarily a conflict between recognizing Fourth Amendment rights as vesting in the individual and as vesting in the people. The gay rights example shows first that recognizing the ways in which individual self-concept is linked to group identification and group fate means that individual rights must partly be defined by how they affect salient sub-communities; second, that individual rights so defined help to promote respect for both individuals and their important groups; and, third, that such individual rights provide a tool for promoting group political mobilization and power, thereby enhancing individual voices through the groups with which they most closely identify. Moreover, because defining individual rights in part by reference to the fate of subordinated groups necessarily appeals to notions of equal worth and power, group voices can thus enhance the sense of being part of a broader political community of shared values. See, e.g., GUINIER \& TORRES, supra note 193, at 105, 172 ("political race" can sustain vital cross-racial coalitions because it embraces a participatory vision of governance that benefits us all). This enhanced sense of activism, respect, and equality stemming from institutions properly designed to serve Fourth Amendment values thus promotes true democracy and best serves the "people." Professor Christopher L. Eisgruber has made a similar point in a different context:

Popular sovereignty is an attractive idea only if we interpret "the people" to refer to "the whole people," and not just a majority, or any other part, of the people. It demands a government that is inclusive enough so that all people (and not merely the majority) can associate themselves with the project of self-government. To qualify as democratic, a government must respond to the interests and opinions of all the people, rather than merely serving the majority, or some other fraction of the people.

Christopher L. Eisgruber, Constitutional Self-Government 19 (2001). Cf. Guinier \& TORRES, supra note 193, at 105 (“"Thus, the Negro, in his struggle to secure his own rights is destined to enlarge democracy for all the people, in both a political and a social sense."') (quoting Rev. Dr. Martin Luther King, Jr.).

254. See GERSTMANN, supra note 251 (implicitly making a similar point). 
analogous question whether gays should constitute a "suspect class" for equal protection purposes, Professor David Richards has said:

An analysis based on political powerlessness wrongly suggests that the gains in political solidarity of groups subjected to deep racial, sexist, or religious prejudice (in virtue of resistance to such prejudice) disentitle them from constitutional protection, as if the often meager political gains of blacks, women, and gays and lesbians (when measured against their claims of justice) are the measure of constitutional justice. This analysis preposterously denies constitutional protection to women because they are a statistical majority of voters. The "political weakness" approach also proves too much: it extends protection to any political group, though subject to no history of rights - denying prejudice, solely because it has not been as politically successful as it might have been (e.g., dentists). Such models of suspect classification analysis suppress the underlying substantive rights-based normative judgments in terms of which equal protection should be and has been interpreted. They ... [do not] afford a sound normative model with which to criticize the case law. ${ }^{255}$

Community and group needs, of course, enter into the analysis of whether to recognize a constitutional right and how to determine its scope. ${ }^{256}$ Once a right is recognized as fundamental, however, the right generally resides, in our tradition, in the individual. ${ }^{257}$ Though even more expansive protections may best be provided by the legislature or the executive, the courts remain bound by the obligation to provide a minimal level of constitutional protection for the individual. ${ }^{258}$ That, in turn, best helps to protect groups and communities.

Had advanced invasive technologies been available at the start of the gay rights movement - and had those technologies' use been deemed "nonsearches"- the movement would have lost the use of procedural privacy rights discourse as a political tool. ${ }^{259}$ Without protection against widespread use of warrantless "searches," prosecution of gays for violating sexual orientation-

255. RICHARDS, IDENTITY AND GAY RIGHTS, supra note 228, at 11 . On the frequent blindness of a majority to the continuing oppression of a minority, see, for example, RICHARD DELGADO \& JEAN Stefancic, Must We Defend Nazis?: Hate SPEech, PORnOGRaphy, AND THE New First AMENDMENT 82-87 (1997) (explaining social and psychological forces that make it hard for majorities to recognize racism); GUINIER \& TORRES, supra note 193, at 37-62 (many conservatives and liberals alike embrace a colorblind ideology that masks entrenched racial inequality and implicitly embraces the idea that overt racism is largely dead). For an analysis of how individual rights recognition promotes healthier and more unified communities, see SAMUEL WALKER, THE RIGHTS REVOLUTION: RIGHTS AND COMMUNITY IN MODERN AMERICA (1998).

256. See RiCHARDS, IDENTITY AND GAY Rights, supra note 226, at 11.

257. See generally Milton R. Konvitz, Fundamental Rights: History OF A CONSTITUTIONAL DOCTRINE (2001).

258. Cf. Luna, Sovereignty and Suspicion, supra note 252, at 809-48 (arguing against "neo-political process" models of the Fourth Amendment, partly because they ignore the continuing importance of the judiciary in defending some minimal level of constitutional protection necessary to defending individual sovereignty); Erik Luna, Constitutional Roadmaps, 90 J. CRIM. L. \& CRIMINOLOGY 1125 (2000) [hereinafter Constitutional Roadmaps] (arguing that courts can aid legislatures in providing remedies and protections for constitutional rights in ways that the judiciary alone cannot by striking down legislation that encroaches on constitutional minima while offering "roadmaps" for how the legislature can do a better job the next time around).

259. See GERSTMANN, supra note 251, at 91-142 (explaining how the Court's stingy privacy rights discourse harmed gay interests in the political battle over Colorado's efforts to limit gay rights by amending Colorado's state constitution. Although the United States Supreme Court ultimately struck down the amendment, it is unclear to what extent it expanded privacy rights discourse to embrace the gay community's concerns). 
biased legislation might have continued unabated. Many individuals whose sense of identity was rooted in an affiliation with the gay community, as well as the community itself, might have long continued to experience the routine humiliation and insult of the state's invading their intimate lives.

2. The Disorderly and the Disreputable. The history of the gay rights struggle shows the ways in which dominant cultural understandings can mark some groups as deserving of privacy and some not. Currently, the "broken windows" theory and "order-maintenance policing" embrace just such an effort. ${ }^{260}$ The underlying idea of these policing theories is that there are dichotomies of persons, "orderly versus disorderly," "reputable versus disreputable," and "predictable versus unpredictable" people. ${ }^{261}$ The "disorderly, disreputable, and unpredictable" include the homeless, vagrants, public drunks, loiterers, and litterers. Once thought to be at most annoyances to others, order-maintenance policing advocates now declare these persons collectively as the sources of a message that the community cares little about enforcing cohesive social norms, and that the law is, in effect, a paper tiger. ${ }^{262}$ In turn, say these theorists, others are encouraged to commit more serious crimes, leading to a cycle of violence, fear, and further disorder. The solution: mass stop-and-frisks, mass suspicionless searches of housing projects, prohibitions against "loitering" with known gang members, and aggressive, even repeated, arrests of minor misdemeanants. ${ }^{263}$ The "disreputable" become the "dangerous," and the known dangerous have little privacy protection. ${ }^{264}$

Social theorist Bernard Harcourt has documented the many flaws in ordermaintenance theories. Harcourt maintains that there is little, if any, evidence that the assault on the disreputable reduces serious crime. To the extent it may

260. See Bernard E. Harcourt, Illusion of Order: The False Promise Of Broken WINDOWS POLICING 23-55 (2001) (defining and illustrating the "broken windows" and related "order maintenance" approaches to policing).

261. See id. at 127-59 (defining and explaining these dichotomies and their functions).

262. See id. For a critique of these sorts of policing techniques as a pretense for controlling the poorest, weakest members of our society, see ZERO TOLERANCE: QUALITY OF LIFE AND THE NEW Police BRUTALiTy IN NEW YoRK CITY (Andrea McArdle \& Tanya Erzen eds., 2001) [hereinafter ZERO TOLERANCE].

263. See HARCOURT, supra note 252, at 23-27, 41-55 (explaining the logic of broken windows policing and cataloguing the various initiatives reflecting this new way of thinking).

264. Id. at 163 ("We may judge the person who is out of order-who is dirty or apparently loitering - as dangerous, as a source of transgression, in need of being controlled or banished."). Professor Harcourt continues:

The approach focuses on the presence of the disorderly rather than on the criminal act. It judges the disorderly not simply by giving the individual a criminal record, and not simply by convicting the person, but by turning the individual into someone who needs to be policed and surveyed, relocated and controlled. It facilitates a policy of surveillance, control, and exclusion of the disorderly. The category of the disorderly is the product of broken windows policing, and it promotes a policy of aggressive arrest and detention.

Id. at 150; cf. Stuntz, Distribution, supra note 36, at 1266-67 ("Privacy, in Fourth Amendment terms, is something that [currently] exists only in certain types of spaces; not surprisingly the law protects only where it exists. Rich people have more access to those spaces than poor people; they therefore enjoy more legal protection."). 
do so, the result probably stems from increased police surveillance rather than changing social norms created by "orderly" neighborhoods. ${ }^{265}$ Furthermore, the very idea of "disorder" is defined by the state and enormously enhances police discretion. In some neighborhoods, for example, sitting on building stoops to chat and "hang out" on the street are considered part of a vibrant social life, rather than loitering or creating the possibility of future criminality. ${ }^{266}$ Moreover, the definition of some as disreputable turns them "into individuals to be watched, relocated, and excluded ... to be controlled." ${ }^{267}$ Rather than condemning the act of loitering, we condemn the loiterer himself as an inferior and dangerous person possessing unsavory attitudes and values. ${ }^{268}$ The very police policies crafted to control or banish the disreputable, however, shape the rest of us as well. Harcourt explains:

Mass building searches in the inner city are going to affect our conception of privacy, of authority, of political power, and of citizenship. Youth curfew laws are going to have an impact on the cultural and intellectual lives of our children. Anti-loitering ordinances will have an effect on street life. Curfews and anti-loitering ordinances will result in police records and contribute to legal or extralegal disenfranchisement. Policing techniques shape us. I am not thinking simply about the fact that the police may want to extend a practice such as mass building searches outside the inner city—which certainly may happen. I am thinking about the fact that the very occurrence of these police practices affects all of us. ${ }^{269}$

There are numerous alternatives to mass humiliation and privacy invasion, whether our goal is to lower crime or to strengthen order. ${ }^{270}$ For example, "target-hardening," such as designing subway turnstiles that cannot be jumped to prevent minor offenses such as fare-beating, may be tried. ${ }^{271}$ Public works programs for the homeless, such as a successful, privately funded project now functioning on a small scale in New York City, can replace arrests. ${ }^{272}$ Even gun crackdowns can be less intrusive and costly if police request consent to search a person or home for guns on the condition not to prosecute if weapons are found, an approach being used with some success in St. Louis. ${ }^{273}$ These alternatives are especially important because current "quality of life initiatives" have

265. HARCOURT, supra note 260, at 150 ("The disorderly may be the wrong target-or, at least, there is not sufficient evidence that they are the right target. ... [T] he social scientific data suggest that poverty, stability, collective efficacy, and race-rather than disorder-may account for the discrepancies in neighborhood crime levels.").

266. Id. at 130 .

267. Id. at 163 .

268. Id.

269. Id.

270. Id. at 221; see generally SUSAN L. MiLler, GENDER AND COMMUNITY POLICING: WALKING THE TALK (1999) (arguing that a true "community policing" style embracing trust, cooperation, compassion, interpersonal communication, and conflict resolution is, in many contexts, more effective than paramilitary or aggressive enforcement-oriented policing); Alexander Tseis, Eliminating the Destitution of America's Homeless: A Fair, Federal Approach, 10 TEMP. POL. \& CIV. RTS. L. REV. 103 (2000) (arguing that serious job training programs are ultimately likely to be more cost-effective than aggressive policing in curing social problems associated with homelessness).

271. HARCOURT, supra note 260, at 221.

272. Id. at 222-23; Tseis, supra note 270.

273. HARCOURT, supra note 260, at 223-24. 
disproportionately impacted minorities while reinforcing the stereotype of black criminality. ${ }^{274}$ Heightened arrests of blacks reinforce these stereotypes and create a vicious circle. ${ }^{275}$ Technological advances, making the monitoring of the "disorderly" easier and more effective, may only worsen these trends. ${ }^{276}$

Professor David Harris illustrates this last point in the context of "electronic frisks" using concealed weapons detectors. ${ }^{27}$ Such frisks would have many advantages, notably reducing the burden imposed on suspects (who would not know they had been frisked) and likely increasing the accuracy of finding weapons over that currently attained by traditional stops and frisks. ${ }^{278}$ Yet such detectors-precisely because they are less burdensome-may, under current Fourth Amendment precedent, be deemed "non-searches," thus entirely free from constitutional scrutiny. ${ }^{279}$ Without such scrutiny, there is no reason to believe that these devices will be used in ways that escape the class and racial biases often evident in current police practices:

[W] hat reason is there to believe that these devices will be handled in a way that is any more racially and ethnically even handed than what the New York Attorney General's report shows us regarding traditional stops and frisks? As that report showed, African Americans and Latinos were much more likely to be stopped and frisked than whites, even controlling for racial composition and crime rate of precincts. And as is now well known, other high-discretion police tactics like the use of traffic stops show similar patterns of racial bias. In fact, would we not expect the same patterns to show up? Perhaps the biases would be worse, since the potential cost (in terms of risk taken by police) of an electronic frisk is actually lower for the officer than when an officer performs a traditional frisk. Thus using these devices would seem quite unlikely to get rid of racial profiling or similar tactics.

A related relevant phenomenon is that the poor in urban areas, who are also disproportionately racial minorities, simply have less privacy than the rich. "People with more money are more likely to live in detached houses with yards; people with less money are more likely to live in apartment buildings with common hallways." 281 Yet, "[b]ecause others can hear (sometimes smell) from the hallway what goes on inside apartments, the police can too. My neighbors cannot freely surround my house to hear what is happening inside; conse-

274. Id. at $171,213$.

275. Id. at 171. See generally GLENN C. LOURY, THE ANATOMY OF RACIAL InEQuAlity 29-43, 60-73 (2002) (explaining the roles of stigma and self-fulfilling prophecies, based on cognitive preconceptions, in perpetuating racial subordination).

276. See generally Harris, supra note 19.

277. Id. at 4-7 (describing the technology).

278. Id. at 7-9.

279. Id. at 12 ("Put simply, the Court's inclination to see technologically-enhanced searches as "nonsearches" for Fourth Amendment purposes, because they are so unintrusive, will put the law permanently behind technology in any societal consideration of what type of surveillance or search activity should take place."); see also supra Part II (describing technology and privacy case law).

280. Harris, supra note 19, at 10; see also Eliot Spitzer, The New York Police Department's "Stop \& Frisk" Practices: A Report to the People of the State of New York from the Office of the Attorney General (Dec. 1, 1999). Professor Harris notes the problems stemming from the absence of constitutional regulation of much police technology, but he does not offer an alternative conception of privacy to that now used by the Court, a task I seek to accomplish in this article.

281. Stuntz, Distribution, supra note 35 , at 1270. 
quently, neither can the police." ${ }^{282}$ Also, because the urban poor live in less comfortable places, they are more likely to spend less time in them than do the rich. "Other forms of entertainment are," however, "more costly than sitting on a front stoop or wandering the streets and talking to friends." ${ }^{283}$ There are more pedestrians on the street in poorer neighborhoods than in richer ones, subjecting the poor to observation by others. The poor are also more likely to work on assembly lines, shop floors, or hotel kitchens in which they share workspace with others, rendering them subject to surveillance if their employer permits it or if their workspace is open to the public. ${ }^{284}$ Current precedent, which rejects the idea that we have a privacy interest when there is a significant probability that other citizens can watch us, thus offers far less protection overall to the poor than to the rich. ${ }^{285}$ The expanded use of police sensory-enhancement technology will often not invade any expectation of privacy that the law recognizes as reasonable. The social and individual costs of using these technologies will, therefore, once again fall disproportionately on the urban poor, a subset of whom constitute the "disorderly" persons order-maintenance policing seeks to control. ${ }^{286}$

There is little indication that the poor and disreputable are organizing effective political resistance; the courts also do not appear to offer much aid. The unsubstantiated claims of order-maintenance theorists are widely accepted, even among many members of poor, minority communities. ${ }^{287}$ Political support

282. Id.

283. Id. at 1271.

284. See id. at 1270-71 (on the poor as pedestrians and as workers).

285. See supra Part II (summarizing the case law).

286. See supra text accompanying notes $249-57$ (defining the "disorderly" and their role in ordermaintenance policing). The distributive problems raised by the Court's current conception of privacy lead Professor William Stuntz to question the value of protecting privacy under the Fourth Amendment, unless privacy is dramatically redefined to "focus not on the interest in keeping things secret or being free of observation, but on the interest in being free from humiliation or indignity, or the interest in avoiding the stigma that comes from being publicly identified as a criminal suspect." Stuntz, Distribution, supra note 35, at 1273. Stuntz concludes, "Privacy's bias can be done away with, but only by protecting something other than privacy." Id. at 1274. This is not quite right. I am in the process of articulating a comprehensive Fourth Amendment theory rooted in the idea of "respect." See Taslitz, Stories, supra note 35 (summarizing this theory). "Privacy," properly understood, plays a special role in ensuring that all persons are treated with equal respect. This article illustrates some of the ways in which privacy accomplishes this goal. The concepts of "dignity" and "privacy" are, contra Stuntz, therefore not mutually exclusive, the latter in part serving an important supportive role in achieving the former.

287. See, e.g., Andrea McArdle, Introduction, in ZERO TOLERANCE, supra note 262, at 5-11 (urging a coalitional strategy because thus far there have been insufficient political forces working against order-maintenance policing but powerful forces supporting it); Tracey L. Meares \& Dan M. Kahan, When Rights Are Wrong: The Paradox of Unwanted Rights, in URGENT TIMES: POLICING AND RIGHTS IN INNER-CITY COMMUNITIES 3, 18-19 (1999) (arguing that a majority of poor, minority, inner-city residents favor order-maintenance policing as a way of attaining neighborhood safety). Guinier and Torres's theory of "political race"- - using racial consciousness and justice appeals as a way to motivate cross-racial coalitions and political action - may, if widely embraced, suggest a more hopeful future that may in the long-term help the "disreputable" to escape their current fate. See GUINIER \& TORRES, supra note 193, at 94-105 ("political race" appeals can help bridge within-class differences, promoting a shared sense of commonality and a willingness to agitate for social change); see also supra text accompanying notes 228-58 (illustrating how privacy rights recognition can enhance group political power). 
is strong, and, in the process, groups and their members unnecessarily suffer increasing physical, status, and emotional harms while our wider notions of privacy and equality contract and erode. ${ }^{288}$ Even the partial success of the gay rights movement in gaining privacy protection is a far rosier scenario than the future prospect of such success among the "disorderly."

\section{Privacy in Public}

Privacy, when defined as the boundary-maintenance necessary to individual and group definition, recognizes - in a way that the Supreme Court and many commentators do not-that the "private" can happen in "public." We do not shed all privacy expectations simply because we walk on a public street, or enter a classroom, or attend a ball game. ${ }^{289}$

Rules of looking make the point. Briefly looking at another permits the initial gathering of visual information without either party committing himself to further interaction. ${ }^{290}$ Two parties who recognize one another or want to invite more intimate contact may mutually consent to longer and more frequent looking. But being looked at by strangers unsettles us. ${ }^{291}$ Looking too long, too intently, or too often becomes "staring," an "invasion of the exoself of another for the gratification of the looker." called the rules of "civil inattention," not deemed to have been seen or heard."

Similarly, the forced close quarters of a crowded elevator make more than the briefest of glances invasive:

Moreover, because much of the class and racial disparities in privacy protection stem from the complete lack of privacy rights when on the street, the willingness of courts at least sometimes to recognize the existence of "privacy in public" can aid in reducing such disparities and enhancing the political power of the disreputable poor. See infra text accompanying Part III.C (defining and defending the idea of privacy on the streets).

288. See McArdle, supra note 262, at 5-11 (on the strength of political support); Harris, supra note 19, at 13 (worrying that legislative protections against police uses of the new surveillance technologies are unlikely). Harris theorizes that the absence of constitutional regulation means that,

[S]ince technology will only improve-it will only get stealthier and more capable as it simultaneously becomes less intrusive-these machines will almost always outpace our ability to decide how we want them used. Instead of making a deliberate, conscious decision about what kind of society we want-[we let the police and technological advancement decide for us]. Do we, in fact, want police to be able to search under the clothing of any citizen, any time, for any reason? Is that the kind of culture we prefer? The technology will drive what happens to us. And one day we will wake up in a society we hardly recognize: no privacy, subject to search whenever we are out in public, under scrutiny a thousand times a day in a Id. hundred ways we cannot imagine now, and may not even be conscious of then.

289. See infra text accompanying notes 275-315.

290. W. MichaEl REISMAN, LAW IN BRIEF ENCOUNTERS 25 (1999).

291. Id. at 29,35 .

292. Id. at 23 .

293. ERving Goffman, Behavior in Public Places: Notes on the Social Organization OF GATHERINGS 85 (1963).

294. REISMAN, supra note 290 , at 24. 
Any mutual exchange of glances on the part of the occupants would bring almost a touch of lewdness to such an already over-cozy sardine formation. Some people gaze instead at the back of the operator's neck, others stare trance-like up at those little lights which flash the floors, as if [the] safety of the trip were dependent upon such concentration.

To be looked up and down by strangers is an indignity, even if only briefly and relatively non-threateningly. The indignity is more major, however, if a large, muscular man repeatedly ogles a female subordinate with whom he works. Indeed, part of the harm done by staring at strangers stems from their fear that those doing the staring may be dangerous sorts and from their uncertainty over when, if ever, the staring will stop. ${ }^{296}$

Jewish law's concept of "bessek re'iyyah," the "injury caused by being seen," is especially attentive to the indignity caused by staring. ${ }^{297}$ This doctrine extends protection even against those who peer at us through an open window facing a common courtyard. Jewish law expresses a worry that the mere risk of being observed without the consent or knowledge of the person observed is a danger. ${ }^{298}$ That risk may inhibit us from speaking and acting freely, inhibiting our lives. Accordingly, Jewish law provides not only for damages against the observer but for an injunction requiring a staring neighbor to relocate any window of his that overlooks the plaintiff's home. ${ }^{299}$ "To whatever extent the unwanted gaze establishes its sway [over the private domain of another], there is injury, because the damage caused by the gaze has no measure," Jewish law declares. ${ }^{300}$ Commentators sympathetic to the Jewish concern with even the risk of unwanted observation thus condemn covert spying as an indignity. ${ }^{301}$ Such spying "fails to treat its objects as deserving of respect, and instead treats them like animals in a zoo, deceiving them about the nature of their own surroundings." 302 Moreover, each of us can sanction unwanted staring of which we are aware. We may glare back, grimace, express distaste, or verbally protest, responses that usually discourage the watcher, ${ }^{303}$ whose gaze breaches the "involvement shields" that protect the integrity of our control over self-definition. ${ }^{304}$ When we are unaware of that gaze, we lose this power to challenge it. Even if we are

295. Cornelia Otis Skinner, Where to Look, in BOTTOMS UP! 29-30 (1955) (also quoted in GOFFMAN, supra note 293, at 137-38).

296. REISMAN, supra note 290 , at 25.

297. ROSEN, supra note 45, at 18-19.

298. Id. at 18-19.

299. Id.

300. Hezzek Re'iyyah, 8 ENCYLOPEDIA TALMUDIT 673 (1975).

301. RoSEN, supra note 45 , at 214.

302. Id. at 214.

303. REISMAN, supra note 290, at 26-28.

304. See GOFFMAN, supra note 293, at 84; ROSEN, supra note 45, at 15-16 (outlining the implications of Goffman's “involvement shields” concept for self-definition). 
aware of the watching, we feel a sense of violation if our only recourse is to flee, perhaps from places or activities that we do not wish to leave. ${ }^{305}$

That sense of violation is connected to our implicit understanding of our exoself-the part of our self that we choose to present to others-as proprietary. ${ }^{306}$ "People may look," we believe, "but they are expected to look at those parts that the owner of the exoself wants them to look at, at appropriate times and following certain procedures." ${ }^{307}$ Furthermore, polite behavior mandates that others at least publicly accept "the exoself as presented by its owner," that is, take it at face value. ${ }^{308}$ Proper and improper ways of looking vary with culture, class, gender, and social function, as well as time and situation. ${ }^{309}$ Invasive looks range from objectification to exploitation. "What woman cannot attest to the difference between a look of respectful admiration and a leer or ogle?"311

The license to stare reflects and creates power. The super-ordinate male might ogle while the subordinate female lowers her eyes. ${ }^{312}$ Professor Patricia Williams told this story to make a similar point about racial subordination:

I decided to go on a walking tour of Harlem. The tour . . except for myself, was attended exclusively by young, white, urban, professional, real estate speculators.... $[T]$ he guide asked the group if they wanted to "go inside some churches." The guide added, "... we'll probably get to see some services going on ... Easter Sunday in Harlem is quite a show."... What astonished me was that no one had asked the people in the churches if they minded being stared at like living museums. I wondered what would happen if a group of blue-jeaned blacks were to walk uninvited into a synagogue on Passover or St. Anthony's of Padua in the middle of High Mass. ${ }^{313}$

Who looks at us, how they do so, for how long, and for what purposes matters. Our awareness or ignorance of their looking matters too. Privacy invasion and the subordination it imposes on individuals and groups can happen on a public street as well as in a home. When technology enables the government to stare with an ever-vigilant and suspicious eye, the boundaries of the self may partly dissolve, reconstructed in the image chosen by the Leviathan. ${ }^{314}$

305. Cf. Rosen, Watchful State, supra note 46, at 93 (stating that camera surveillance in public places involves "technologies of classification and exclusion. They are ways of ... deciding who gets in and who stays out, of limiting people's movement and restricting their opportunities.").

306. REISMAN, supra note 290 , at 31.

307. Id.

308. Id.

309. Id. at 31-32.

310. Id. at 32 .

311. Id.

312. Id. at 35 .

313. Patricia Williams, Spirit-Murdering the Messenger: The Discourse of Fingerpointing as the Law's Response to Racism, 42 MIAMI L. REV. 127, 149 (1987); see generally PATRICIA WILLIAMS, THE ALCHEMY OF RACE AND RIGHTS (1991).

314. See louis Michael Seidman, Our Unsettled Constitution: A New Defense Of CONSTITUTIONALISM AND JUDICIAL REVIEW 35 (2001) ("[T] here is the strategy [for maintaining political stability and order] embraced by Hobbes himself - the creation of an all-powerful state with the ability, through brute force, to suppress destabilizing disagreement."); Anupam Chander, Diaspora Bonds, 76 N.Y.U. L. REV. 1005, 1017 n.56 (2001) (Hobbes' "Leviathan" is a state in which citizens submit to its will); see generally THOMAS HOBBES, LEVIATHAN (Oxford, Clarendon Press 1967) (1651). 
Lest this analysis seem overstated, it is important to mention that Great Britain has long used video-surveillance technology as a policing tool in public places. ${ }^{315}$ Governmental video-monitoring is far more widespread in England than it is here. ${ }^{316}$ Yet many, perhaps most, Britons seem to welcome the surveillance. ${ }^{317}$ If this is so, why should we be any more troubled by the new surveillance technologies than are the British?

Professor Post's analysis of the social function of privacy torts again helps to answer this question. Post explains the true meaning of the "reasonable person" idea in the law governing the tort of intrusion upon seclusion thusly:

Because the reasonable person is not simply an empirical or statistical "average" of what most people in the community believe, the mental distress at issue in defining liability cannot be understood as a mere empirical or statistical prediction about what the majority of persons in a community would be likely to experience. Instead, because the reasonable person is a genuine instantiation of community norms, the concept of offensiveness ... must be understood as a quality that inheres in such norms. ${ }^{318}$

Therefore, Post concludes, the question whether a plaintiff is entitled to relief is best phrased this way: "[Has the] defendant ... transgressed the kind of social norms whose violation [c]ould properly be viewed with outrage or affront?",119 This question in turn "rests on the premise that the integrity of individual personality is dependent upon the observance of certain kinds of social norms." ${ }^{320}$

Post's comments are best understood as saying that the kind of persons we are and the kind we (society) wish to be both matter in deciding when an individual victim of invasion of privacy is entitled to feel the "outrage" that is associated with attacks on individual personality. ${ }^{321}$ American culture is significantly

315. See WHITAKER, supra note 172, at 83 ("The United Kingdom has taken urban surveillance for policing perhaps further than any other Western country. It has become relatively common in British town centers to have comprehensive street surveillance in place.").

316. Id. at 304.

317. See Rosen, Watchful State, supra note 46, at 40-44, 92-93. Professor Rosen explains:

Instead of being perceived as an Orwellian intrusion, the cameras in Britain proved to be extremely popular. They were hailed as the people's technology, a friendly eye in the sky, not Big Brother at all but a kindly and watchful uncle or aunt. Local governments couldn't get enough of them; each hamlet and fen in the British countryside wanted its own CCTV surveillance system, even when the most serious threat to public safety was coming from the mad cows.

Id. at 41.

318. Post, supra note 211, at 54.

319. Id.

320. Id.

321. "Social norms" is a term variously defined, though among the better known definitions is Cass Sunstein's: "[W]e might, very roughly, understand 'norms' to be social attitudes of approval and disapproval, specifying what ought to be done and what ought not to be done." CASS SUNSTEIN, FREE MARKETS AND SOCIAL JUSTICE 38-39 (1997). So understood, Post's reference to "social norms" can be read as referring to widespread current social attitudes. Yet his emphasis on the non-empirical, nonmajoritarian nature of the reasonableness inquiry in privacy torts suggests that he embraces a primarily normative notion of reasonableness and privacy, one that turns on what attitudes and emotions Americans should feel. That may indeed be why he phrases his test not in terms of all social norms or actual outrage at any of their violation but only in terms of those particular relevant social norms that are "the kind ... whose violation can properly be viewed with . . . affront." POST, supra note 211, at 54. Such a reading would be most consistent with substantive criminal law commentators' theory of the "evaluative" concept of the emotions, that is, that individuals' emotions are subject to change by themselves or 
more individualistic and distrustful of government than is British culture. ${ }^{322}$ Americans therefore more tightly embrace those liberties that keep our sense of self relatively distinct from that sought to be created by the state. Thus, the British have embraced limitations on free speech, on the right to a jury trial, and on the privilege against self-incrimination that we have not. ${ }^{323}$ On the other

with the aid of the law and are thus subject to moral censure. See Andrew E. Taslitz, Two Concepts of the Emotions in Date Rape, 15 WIS. WOMEN's L.J. 3, 9-12 (2000) (summarizing these views). My argument here is thus primarily about what privacy invasions should outrage Americans as a matter of political morality, a question partly informed by what does outrage us.

322. See Rosen, Watchful State, supra note 46, at 93. Professor Rosen elaborates:

Perhaps the reason that Britain has embraced these technologies of surveillance, while America, at least before Sept. 11, had strenuously resisted them, is that British society is far more accepting of social classifications than we are. The British desire to put people in their place is the central focus of British literature, from Dickens to ... [George] Orwell's... [early] book "The English People."

... In many ways, the closed-circuit television cameras have only exaggerated the qualities of the British national character that Orwell identified in his less famous book: the acceptance of social hierarchy combined with the gentleness that leads people to wait in orderly lines at taxi stands; a deference to authority combined with an appealing tolerance of hypocrisy. These English qualities have their charms, but they are not American qualities.

Id. at 93. Rosen illustrates the ways in which CCTV cameras can "put people in their place," that is, promote deference and conformity, by observing that some gay men who previously kissed their lovers in public now fear doing so and that shopping mall managers regularly and successfully bar those whom they see as "misbehaving" from malls. Id. at 42, 93. Moreover, says Rosen, there is strong evidence that CCTV cameras neither prevent terrorism nor other crime. Id. at 92 . Furthermore, the cameras are more likely to be used against racial minorities, thus exacerbating racial profiling and making the cameras "far less popular among black men than among British men as a whole." Id. Concludes Rosen, "rather than thwarting serious crime, the cameras are being used to enforce social conformity in a way that Americans may prefer to avoid." Id. at 42.

Americans may, and certainly should, avoid the British example, Rosen argues, because of our very different national character:

Like Germany and France which are squeamish about CCTV because of their experience with 20th-century totalitarianism, Americans are less willing than the British to trust the government and defer to authority ....

The promise of America is a promise that we can escape from the Old World, a world where people know their place. When we say we are fighting for an open society, we don't mean a transparent society-one where neighbors can peer into each other's windows using the joysticks on their laptops. We mean a society open to the possibility that people can redefine and reinvent themselves every day; a society in which people can travel from place to place without showing their papers and being encumbered by their past; a society that respects privacy and constantly reshuffles social hierarchy.

....

If the 21 st century proves to be a time when this ideal is abandoned-a time of surveillance cameras and creepy biometric face scanning in Times Square-then Osama bin Laden will have inflicted an even more terrible blow than we now imagine.

Id. at 93. For a detailed exploration of the history and social science supporting an American conception of Fourth Amendment interests in privacy, property, and freedom of movement, see generally

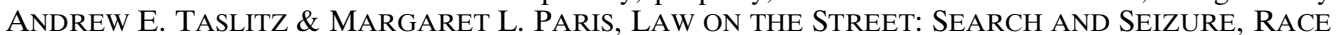
AND RESPECT IN AMERICAN LIFE (forthcoming 2003). See also Taslitz, Racist Personality, supra note 178 (discussing our constitutional system's concern with encouraging particular character traits deemed necessary to the American conception of a free people).

323. See, e.g., Ray Moseley, Free Press v. Fair Trial, CHI. TrIB., Oct. 11, 1995, at 4 (noting that "American law gives pre-eminence to [First] Amendment rights to free speech, while British law puts more emphasis on a defendant's right to a fair trial"); Sally Lloyd-Bostock \& Cheryl Thomas, The Continuing Decline of the English Jury, in WORLD JURY SYSTEMS 53-91 (Neil Vidmar ed., 2000) (describing the history of the English jury and its subsequent decline in the twentieth century); GARY SLAPPER \& DAVID KELLY, PRINCIPLES OF THE ENGLISH LEGAL SYSTEM 261-62 (3d ed. 1997) (stating 
hand, as Justice Harlan has explained, the law can help to "form and project" as well as reflect community norms. ${ }^{324}$ The ultimate question becomes whether, as a matter of political morality, we want to encourage a more docile, conformist, less autonomous people. To reject that choice in favor of its opposite does not mean that video surveillance is never appropriate. Proven need (such as heightened safety dangers), combined with appropriate safeguards, may justify such action. ${ }^{325}$ To recognize that constitutional questions are involved, that the state must justify its actions, and that it must implement surveillance programs in a reasonable manner, however, is to recognize that the default position is no surveillance. The injury to human dignity stems not so much from the watching as from doing so without adequate justifications and limitations. ${ }^{326}$ Regulation preserves the idea of a diverse, noisy America, where citizens are free to get lost in the crowd and where their sense of self stems from their chosen affiliations and actions rather than from the all-seeing gaze of the state.

\section{Information Disclosure}

The boundaries that mark our sense of self extend not only to direct observation of our person and activities, but to "information preserves." ${ }^{227}$ Our need to control those aspects of ourselves that we reveal to others includes the desire to regulate the content of the information about self that we expose, as well as the context of the disclosure: to whom, at what time, and in what manner revelations are made. ${ }^{328}$ Information revelation beyond what we choose violates the

that the "right to silence" was effectively abolished in the Criminal Justice and Public Order Act of 1994).

324. See United States v. White, 40 U.S. 745, 786 (1971) (Harlan, J., dissenting) ("Since it is the task of law to form and project, as well as mirror and reflect, we should not, as judges, merely recite the expectations and risks without examining the desirability of saddling them upon society.").

325. Cf. Slobogin, supra note 48, at 442-43, 458-59 (taking a similar, albeit not identical, approach). Slobogin interestingly notes that the first draft of the ABA Technologically-Assisted Physical Surveillance standards concluded that surveillance regulation would pose "a significant infringement of other widely-shared values in a democratic society, including the enjoyment of anonymity and places of repose, the absence of a pervasive police presence, and the absence of intensive official scrutiny except in response to suspicious conduct." Id. at 430 . This language was eventually deleted because several ABA Task Force members found it too vague. Id. Slobogin considered the quoted language to capture interests "not clearly encompassed by the privacy concept." Id. His observation is probably correct concerning the Court's current definition of privacy but is incorrect concerning the conception that I use here.

326. See Colb, Targeting Harm, supra note 44, at 1487 ("The harm that [a person searched without probable cause] but not [searched with probable cause] experiences is the targeting harm, the harm of being singled out from others through the exercise of official discretion that is not based on an adequate evidentiary foundation" (emphasis added).).

327. See Erving Goffman, Territories of the Self, in RELATIONS IN PUBLIC: MicRostudiES OF THE PUBLIC ORDER 38-40 (1971) (describing "information preserves" as a set of facts about an individual to which he or she expects to control access while in the presence of others); see also RosEN, supra note 45, at 122-23 (summarizing Goffman's theory that even in the workplace, we each need "backstage areas" to give employees a refuge from social expectations, areas in which conduct may deviate from the "front stage" norms that protect us from unwanted intimacy).

328. POST, supra note 211, at 68-69; RosEn, supra note 45, at 72-73. See also infra text accompanying notes 330-74. 
"territories of the self," being experienced "as a pollution or defilement" of personality. ${ }^{329}$

Case law concerning the tort of public disclosure of private facts recognizes the importance of information preserves to protecting human personality. The two most important elements of that tort for my purposes here are that a communication must be (1) about "a matter concerning the private life of another," and (2) "of a kind that would be highly offensive to a reasonable person."

The first element requires assessment of both the content and circumstances under which data is revealed. ${ }^{331}$ In Briscoe v. Readers' Digest Association, the plaintiff, who had for years been leading an exemplary life, sued Readers' Digest for its publication of a story noting his conviction for hijacking a truck eleven years earlier. ${ }^{332}$ The Court held for the plaintiff, even though his identity as a convict had previously been revealed to the public in a national magazine story near the time of the hijacking, ten years earlier. As constitutional law professor Robert Post explains, "The court's conclusion makes sense only if it is read as resting on the perception that it is somehow deeply inappropriate for the defendant to have revealed the plaintiff's identity in that way, or at that time, or to that audience," because the content of the disclosure had long ago been revealed to the public. ${ }^{333}$ The Briscoe court relied on a California Supreme Court decision, Melvin v. Reid, ${ }^{334}$ that supports Post's reading of the Briscoe decision. In Melvin, the California Supreme Court upheld a plaintiff's victory in a privacy disclosure action based on a movie that the defendant made that accurately identified the plaintiff as a notorious prostitute and accused felon. The California court described the movie as made in "willful and wanton disregard of that charity which should actuate us in our social intercourse and which should keep us from unnecessarily holding another up to the scorn and contempt of upright members of society., ${ }^{335}$

The second element of the disclosure tort-whether the revelation is one that "would be highly offensive to a reasonable person"--similarly turns on more than the revelation's content or its previous disclosure to certain other persons. ${ }^{336}$ The disclosure to a debtor's employer of the existence of the debt and the debtor's failure to pay it is generally not invasive of privacy or offensive to a reasonable person. ${ }^{337}$ This is so because the debtor does or should understand that the creditor can take reasonable steps "to pursue his debtor and per-

329. Post, supra note 211, at 73; Erving Goffman, Territories of the Self, supra note 327, at 28-29, 31, 28-29, 40-44, 60.

330. Post, supra note 211, at 68.

331. Id. at $68-72$.

332. 483 P. 2 d 34 (1971).

333. Post, supra note 211, at 70.

334. 297 P. 91, 93-94 (Cal. App. 1931).

335. Id.

336. Post, supra note 211, at 71.

337. Id. at 71 (discussing Voneye v. Turner, 240 S.W.2d 588 (Ky. 1951)). 
suade payment." ${ }^{938}$ The creditor's giving undue publicity about the same debt to a wider circle of persons, however, would constitute "oppressive treatment" of the debtor. ${ }^{339}$ For example, a garage mechanic's placement of a five-foot by eight-foot sign in the window of his garage, which overlooked one of the principal streets of a town, announcing the failure of a local veterinarian to pay a debt that he owed to the mechanic, merited damages. The veterinarian's complaint alleged that the sign had caused him "great mental pain, humiliation, and mortification," exposing him to "public contempt, ridicule, aversion, and disgrace," and causing "an evil opinion of him in the minds of tradesmen and of the public generally." ${ }^{340}$ The court implicitly viewed the sign as violative of privacy and generally offensive because of its manner of dissemination and intended audience, not simply because of its content. ${ }^{341}$ The offensiveness and private-facts elements of the disclosure tort are thus quite similar, the former adding merely that only serious transgressions merit damages. ${ }^{342}$ Both elements, however, turn on "social norms governing the flow of information in a modern society," norms sensitive to the purpose, timing, and status of the one making the disclosure and the status and purposes of the addressee. ${ }^{343}$ The disclosure tort's elements thus approximate the common lay understanding of privacy. ${ }^{344}$

The central point here is that the mere fact that information is disclosed to another does not necessarily mean that every reasonable expectation of privacy in the information evaporates. To the contrary, the degree of humiliation and sense of violated personal boundaries that the subject of the disclosure experiences continue to depend on to whom, by whom, when, how, and for what purposes the disclosure is made. That should be no less true when information is passed along to the state than to private parties. ${ }^{345}$

This last observation carries particular force where an initial disclosure is made in a relationship of trust, though that relationship may fall far short of the level of trust among close friends or family members or between doctors and their patients. ${ }^{346}$ An important social science study bears this out, finding that ordinary citizens view the idea of using a chauffeur or a secretary as an undercover agent for the state significantly intrusive of privacy-more intrusive than a frisk; a student locker search; searches of office drawers, suitcases in airports,

338. Harrison v. Humble Oil \& Ref. Co., 264 F. Supp. 89, 92 (D.S.C. 1967) (quoting Cunningham v. Sec. Inv. Co. of St. Louis, 278 F.2d 600, 604 (5th Cir. 1960)).

339. Id. at 92 .

340. Brents v. Morgan, 299 S.W. 967, 968 (Ky. 1927).

341. See Post, supra note 211, at 69, 71 (asserting similar analysis of Brent).

342. Id. at 72 .

343. Id.

344. Id.

345. Indeed, the very existence of the Fourth Amendment seems in part to constitute a recognition that revelation of private information to the state can be particularly worrisome. See LESSIG, supra note 37, at 17-18, 111-18, 148-49 (stating that the Fourth Amendment may fairly be read as regulating information discovery by the state, especially when using technology, and perhaps even when that technology's use imposes minimal burdens on the citizenry while catching only the guilty).

346. For an analysis of the significance of relationships of trust in Fourth Amendment reasoning, see Taslitz, Feminist Fourth Amendment, supra note 156, at 12-20, 48-52. 
and car trunks on public streets; or even arrests, followed by handcuffing and detention for forty-eight hours. ${ }^{347}$ Similarly, citizens find a bank's conveying information about a depositor's records to someone other than a necessary bank employee highly intrusive..$^{348}$ Yet the Supreme Court has held that one "assumes the risk" that an acquaintance to whom one reveals confidences will disclose that information to third parties, as does a bank depositor who assumes the risk that the bank will reveal the depositors' affairs to the government. ${ }^{349}$ This disparity between the public's actual sense of privacy and the Court's sense reveals that "we only assume those risks of unregulated government intrusion that the courts tell us we have to assume." 350

Information disclosure can also affect our intimate relationships and freedom of expression in much the same way as does direct observation of our persons and activities. Sociologist Erving Goffman expresses this idea well: Like actors in a theater, individuals need "backstage areas" where they can doff their public masks and relieve the tensions of public performance. ${ }^{351}$ Backstage, we relax, say more of what we wish, and pursue "odd" or intimate thoughts and feelings more easily. ${ }^{352}$ E-mail exchanges notably "carve out [such] backstage areas where people can joke, let down their hair, and form intimate relationships free of official scrutiny." "353 If we are aware that our words are being monitored, we may choose them more carefully or not speak them at all. This disincentive exists even when our words are thoroughly unrelated to any criminal activity. Again, the primary danger we face is that of being judged out of context, defined by others who possess or disclose only part of our story. ${ }^{354}$

Professor Lawrence Lessig faced just such an abuse of his e-mail communications. Lessig had written an e-mail to a Netscape acquaintance joking that he

347. Christopher Slobogin \& Joseph E. Schumacher, Reasonable Expectations of Privacy and Autonomy in Fourth Amendment Cases: An Empirical Look at "Understandings Recognized and Permitted by Society,” 42 DUKE L.J. 727, 737-38 (1993).

348. Id. at 739-42.

349. See supra text accompanying notes 55-97.

350. Slobogin, supra note 48 , at 400.

351. See Rosen, supra note 45, at 12,122-23 (summarizing Goffman's work).

352. See id. at $12,122-23$.

353. Id. at 89. I think that Rosen has it right on this point and thus reject Robert Post's argument that public disclosure of private information, while violative of principles of respect, does not implicate autonomy values in the same way as does direct observation of intimate activity. See Post, supra note 209, at 74 (setting out this position in the tort context). E-mail communications can be critical to forming intimate relationships, as anyone who has seen the movie, You've Got Mail, in which a romance bloomed primarily on the Internet, knows. Similarly, e-mail exchanges and Internet use aid us in making life choices that deeply affect our sense of self and political options, in this way also implicating our autonomy. See generally CASS SUnSTEIN, REPUBLIC.COM (2001) (exploring the ways in which Internet usage affects individual choice and the character of the citizenry). Moreover, observing e-mail usage in particular is so akin to direct observation by ordinary aural eavesdropping as to be effectively indistinguishable in the harm that it causes. Post rightly recognizes information control as an important privacy interest, see POST, supra note 211 , at 74, but therefore wrongly suggests that its invasion is necessarily less socially harmful than direct observation. See id.

354. See supra text accompanying notes 169-211. 
had "sold [his] soul" by downloading Microsoft's Internet Explorer. ${ }^{355}$ In that same e-mail Lessig inquired of his acquaintance: "When are you in Cambridge? I've moved permanently now, and I'd love to show you the center, and talk and whatever else we can think of doing?"356 When Judge Thomas Penfield Jackson chose Lessig to advise him in overseeing the infamous antitrust case brought against Microsoft by the government, Microsoft officials produced the e-mail, claiming Lessig's "sold [his] soul" comment showed that he was biased against Microsoft and should resign. ${ }^{357}$ Meanwhile, a newspaper in the Northwest incorrectly speculated that Lessig's suggestion that he and his Netscape acquaintance do "whatever else we can think of doing" showed that the two were homosexual lovers. ${ }^{358}$

In fact, what happened was that Lessig downloaded Explorer to enter a contest to win a PowerBook computer. After the download, he realized that his Netscape bookmarks had been erased. Irritated, he sent an e-mail to his Netscape acquaintance, whom he had met at a professional conference, describing the incident and quoting the song then playing on his car stereo: "sold my soul, and nothing happened." ${ }^{359}$ Yet now Lessig found himself erroneously judged by strangers as biased against Microsoft and wrongly cast as involved in an intimate homosexual relationship with one of Microsoft's primary competitors. Lessig felt especially ill-treated because, "in a world of short attention spans, he was never given the chance" to tell the full story to a public willing to listen. ${ }^{360}$

This brings us back full circle to one of the two stories that began this article: that of the Ninth Circuit judges who objected to their e-mail being monitored by the Administrative Office of the federal courts. ${ }^{361}$ Under current substantive law, employers can sometimes be held liable for damages caused by their employees' Internet usage. ${ }^{362}$ Sexually explicit e-mail messages at the workplace can create a "hostile environment," exposing the employer to liability under federal sexual harassment laws. ${ }^{363}$ This liability creates an incentive for employers, including the federal government when acting as an employer, randomly to monitor employee e-mails. A recognition of Fourth Amendment protection for e-mails between or among a small number of parties where the exchanges did not concern particular work tasks would help to preserve e-mails as "backstage

355. See Rosen, supra note 45, at 55 (quoting in part Lawrence Lessig, The Architecture of Privacy (1998), available at http://lessig/org/content/articles (Feb. 6, 2002)).

356. ROSEN, supra note 45 , at 55, 76 .

357. Id. at 55.

358. Id. at 76.

359. Id. at 55 .

360. Id.

361. See supra text accompanying notes 19-29.

362. See ROSEN, supra note 45, at 81 (describing the legal pressures on companies to monitor e-mail and Internet usage in an effort to reduce sexual harassment liability); see also supra notes 20-25 and accompanying text (recounting that the Administrative Office of the Federal Courts monitored judges' email partly because of a fear of liability for illegal e-mail conduct by individual judges).

363. See RosEn, supra note 45, at 79 (making a similar point); Taslitz, Civil Society, supra note 221, at 350-54 (summarizing the law and justifying the theory of hostile environment sexual harassment). 
areas." ${ }^{\$ 364}$ Such a recognition would require extending the exclusionary rule to civil sexual harassment cases against governmental employers. ${ }^{365}$ A sensible constitutional rule would permit the government-as-employer to read or monitor a particular employee's e-mail only where there is individualized suspicion of his wrongdoing. ${ }^{366}$ Thus an employee might complain of receiving harassing electronic missives from a particular fellow employee, creating the necessary suspicion. Such a rule would eliminate the government's incentive randomly to monitor all its employees' e-mail and Internet usage because the results of random searches would be suppressed. Yet the employer still could be expected to intercede where it had a particular suspicion of harassing behavior. ${ }^{367}$ A similar result might be achieved legislatively for private employers without the necessity of radical and politically difficult changes in substantive sexual harassment law. ${ }^{368}$

The objection may still be made that employers, even government employers, own the computers and act in a "managerial" sphere in which efficiency, not public deliberation, autonomy, or personal growth, are the organizing principles. ${ }^{369}$ But:

surely this Taylorite vision of the modern workplace rooted in principles of industrial organization from the 1920s is hard to accept today. As e-mails, modems, and PCs break down the boundaries between work and home, there are progressively fewer private or public spaces for citizens to express themselves autonomously. The Internet has blurred the distinction between the home and the office, as Americans are spending more time at the office and are using company-owned computers and Internet servers to do their work from home. But as technology poses new challenges to geographic concepts of privacy, courts have not been encouraged to think creatively about how to reconstruct zones of individual privacy and free expression. ${ }^{370}$

Finally, information disclosure, like observation of our persons and activities, has implications for group self-definition. For example, the mere revelation of a person's sexual orientation without his consent is deeply invasive of his publicly chosen self, even if he has not been observed engaging in a homosexual

364. See RoSEN, supra note 44 , at 89.

365. The exclusionary rule generally applies only in criminal, not civil, litigation. See TASLITZ \& PARIS, supra note 27, at 479-80. If the rule were applied in civil sexual harassment suits involving the government as an employer, no courtroom use could be made of wrongly monitored e-mail. This solution is simpler than altering substantive sexual harassment law, is therefore more politically viable, and avoids the quagmire of wrestling with the underlying theoretical justifications for laws against sexual harassment.

366. See RosEn, supra note 45, at 90.

367. My evidentiary solution to this problem differs from Rosen's cure, which requires changing the substantive law of sexual harassment. See id. at 127 (arguing that invasion of privacy law is better suited than hostile environment sexual harassment statutes for regulating offensive workplace speech).

368. See generally George, supra note 24 (arguing that Professor Rosen's proposed changes in the substantive statutory law governing hostile environment sexual harassment are unwise, possibly radical, and incompletely justified).

369. Cf. POST, supra note 211, at 236 (arguing for greater governmental authority to limit speech where the state acts in the "managerial sphere"); Andrew E. Taslitz \& Sharon Styles-Anderson, Still Officers of the Court: Why the First Amendment is No Bar to Challenging Racism, Sexism, and Ethnic Bias in the Legal Profession, 9 GEO. J. LEGAL ETHICs 781, 811-812 (1996) (illustrating the application of the "managerial sphere" to the regulation of lawyers' speech in professional contexts).

370. ROSEN, supra note 45 , at 83-84. 
act. $^{371} \mathrm{He}$ faces particular dangers of being judged publicly based on widespread stereotypes about gays, rather than on personalized, detailed knowledge about his complex individual nature. ${ }^{372}$ Correspondingly, if such acontextual disclosures feed stereotypes about gays, the gay community is also harmed. ${ }^{373}$ If such unchosen and acontextual disclosures abound, many gays may be forced either to make extraordinary, burdensome efforts to protect against revelation or to reveal their sexual orientation at times and places, and to audiences, that they otherwise would not choose. Earlier I discussed the unfair revelation of an email written by Lawrence Lessig that was incorrectly interpreted as revealing his sexual orientation to be gay. ${ }^{374}$ Would not the privacy invasion have been equally or more damaging if Lessig had in fact been a closeted gay? ${ }^{375}$ Observation and information disclosure are thus not two separate phenomena but merely two aspects of a single concept, "privacy invasion"-a ripping away of the masks by which we define our very natures.

IV

\section{CONCLUSION}

Just as I finished a draft of this article, I heard the news that terrorists had flown commercial jets into the World Trade Center Towers, ultimately destroying a large chunk of lower Manhattan and killing over 3,000 people. ${ }^{376} \mathrm{~A}$ few minutes later, a similar attack was reported on the Pentagon, resulting in

371. See ESKRIDGE, supra note 232, at 236 ("The main reason antidiscrimination laws generate so few complaints is that most gay employees are not 'out' in the workplace"). Eskridge also describes the military's "don't ask, don't tell" policy that mandates discharge of military personnel who openly acknowledge their sexual orientation as gay. See id. at 174-95. He further describes the history of a gay "double life"- denying one's gay identity in the presence of heterosexuals. See id at 54. Cf. RICHARDS, IDENTITY AND GAY RIGHTS, supra note 226, at 173 ("Abridgement of . . . intimate life play[s] the role ... [it does] in inflicting ... evil because ... [it is] so intimately tied up with the sense of ourselves as embedded in and shaped by networks of relationships to other persons with the moral powers of rational choice and reasonable deliberation over the convictions and attachments that give shape and meaning to our personal and ethical lives.").

372. See id. at 193 (one of the justifications for barring uncloseted gays from the military "appeals to fears that the homosexual secretly lusts after and will attack the heterosexual"); see also RICHARDS, IDENTITY AND GAY RIGHTS, supra note 226, at 173 (explaining that current law and social attitudes often involve "[t]he dehumanization of people, on grounds of . . sexual orientation, impos[ing] objectifying stereotypes of identity (as ... homosexual) that deny these moral powers [of rational choice] indeed that are rationalized in terms of this denial").

373. See ESKRIDGE, supra note 234, at 181, 193 (noting that suppression of open expression seeks to avoid disorder arising from the activation of gay stereotypes once one's sexual orientation is revealed, while, when successful, as is true of all closeting strategies, "discouraging the formation of an openly gay subculture and gay, lesbian, and transgendered political activism"); Taslitz, Racist Personality, supra note 27 , at $758-65$ (explaining how stereotyping harm to individual group members can harm the group as a whole as well).

374. See supra text accompanying notes 354-59.

375. See ESKRIDGE, supra note 371 (describing some of the ill practical and emotional consequences of being "outed" as gay).

376. See Dead and Missing, N.Y. Times, Dec. 18, 2001, at B2 (latest estimate is 3001 persons dead or missing); Michael Grunewald, Terrorists Hijack 4 Airliners, Destroy World Trade Center; Hundreds Dead; Bush Promises Retribution; Military Put On Highest Alert, WAsH. Post, Sept. 12, 2001, at A1 (describing the attacks). 
over 200 deaths. The short-term damage spilled well beyond the sites of the attacks, shutting down commercial flights and the New York Stock Exchange for about one week; later leading to the largest one-week plunge in the stock market since the start of the Great Depression; temporarily crippling the airline, hotel, and related industries; and tipping the nation into recession. ${ }^{377}$ Meanwhile, President George W. Bush declared an expected years-long war on terrorism that promised to forever change Americans' sense of safety and to confront Americans with a seeming choice between sacrificing their liberties or their lives. $^{378}$

When I first heard the news of the terrorist attacks, I put this article aside. How could I argue for expanded constitutional protections in a world where increased surveillance suddenly seemed necessary to saving American lives? Eventually, I returned to my manuscript, deciding that the choice between safety and civil liberties was a false one: first, because nothing in my approach is inconsistent with national safety; and, second, because our "nation," as we have come to define it, would de facto cease to exist if we jettisoned our civil liberties from fear. ${ }^{379}$ This latter eventuality would be a true victory for terrorism.

This article is not about terrorism. However, given recent events, it seems important briefly to explain why my approach to Fourth Amendment privacy does not bar effective anti-terrorist actions that respect civil liberties. Doing so will also help to clarify the implications of my thesis.

Most importantly, my argument has been that privacy, and thus constitutional regulation of governmental invasions of that interest, must be more broadly understood than is true under current Supreme Court doctrine. Specifically, I have argued that an affective, rather than a probabilistic-risk conception of privacy recognizes that what happens on the streets, in open view of other citizens, can still merit privacy protection from technologically-enhanced governmental monitoring. Similarly, a citizen's mere disclosure of otherwise private information to one small audience does not necessarily mean that he loses privacy protection against disclosure to other audiences.

377. See Paul Blustein and Carol Vinzant, Stocks Plummet as Wall Street Reopens; Dow Off 685; Fed Cuts Rates in Effort to Contain Losses, WASH. Post, Sept. 18, 2001, at A1; Jane Bryant Quinn, Beating the Second Scare; Wall Street's Nightmare Week, as Fallout From the Attack Breeds Its Own Form of Hope, NewsweEK, Oct. 1, 2001, at 57; David Von Drehle, Nation Reels as Toll Mounts; Bush Denounces "Acts of War," WASH. POST, Sept. 13, 2001, at A1.

378. See Dan Balz, Bush Warns of Casualties of War; President Says Bin Laden Is Wanted "Dead or Alive," WASH. POST, Sept. 18, 2001, at A1; David Von Drehle, Bush Pledges Victory; Reagan National Closed Indefinitely, WASH. POST, Sept. 14, 2001, at A1.

379. See generally HEYMANN, supra note 19 (recommending anti-terrorism policies that would not reduce civil liberties); DEMPSEY \& COLE, supra note 19, at 161 ("Only such a [legal and political] transformation can successfully meet the threat of terrorism without sacrificing our political freedoms."); Nat'l Comm'n on Terrorism, COUNTERING THE CHANgING THREAT OF INTERNATIONAL TERRORISM 9-12 (June 2000) (recommending that changes requiring significant new intrusions on civil liberties not be implemented). On one effort to explore what political and other beliefs define the American national character, see JOHN HARMON MCELROY, AMERICAN BELIEFS: WhAT KeEPS A BIG COUNTRY AND A Diverse PEOPLE UNITED 165-207 (1999) (stressing the cultural importance to the collective American identity of the ideas that the people are sovereign, that governmental power must be limited, and that written constitutionalism defines us as a nation). 
Widening the scope of governmental technological surveillance that is deemed to implicate constitutional privacy interests means only that such invasions must be "reasonable." probable cause and a warrant. ${ }^{381}$ The Court has recognized, however, that those requirements can be modified for "administrative" searches designed primarily to protect against imminent, broad-impact threats to physical safety where traditional safeguards will likely fail. ${ }^{382}$ For similar reasons, the usual rules may need to be modified in the face of rising threats of mass destruction by terrorists. ${ }^{383}$ Even if modifications are necessary, infringements on traditional civil liberties should be minimized precisely to avoid an indirect sort of victory by the terrorists. Most importantly, constitutional regulation requires all branches of government to demand adequate and proven justifications for impinging upon privacy while seeking viable alternatives to such impingement. ${ }^{384}$

In the context of video surveillance, the American Bar Association Tentative Draft Standards on Technologically-Assisted Surveillance provide a useful starting point. Proposed Standard $\S 2-6.3$ permits "overt" video surveillance, that is, surveillance of which a reasonable person should be aware. ${ }^{385}$ Such surveillance, however, is permitted only if several conditions are met: (1) a politically accountable law enforcement official or the relevant politically accountable governmental authority concludes that such surveillance will be "reasonably likely" to achieve a legitimate law enforcement objective; and (2) the public to be affected by the surveillance: (a) is notified of the intended location and general capability of the camera; and (b) has the opportunity, both be-

380. U.S. CONST. amend IV.

381. TASLITZ \& PARIS, supra note 27 , at 83.

382. See id. at 349-75 (summarizing case law).

383. See NAT'L RESEARCH COUNCIL, CONTAINING THE THREAT From Illegal Bombings $117-$ 53, 156-58 (1998) [hereinafter NRC Report] (arguing that governmental efforts to limit the damage done by bomb-blast terrorism must rise as the threat level rises).

384. See generally KonviTZ, supra note 257, at 148 (explaining that fundamental rights can be infringed only if they are the least restrictive alternative for protecting compelling governmental interests, a general constitutional principle strangely ignored by the Court in much of its Fourth Amendment jurisprudence); ANDREW E. TASLITZ, RAPE AND THE CULTURE OF THE COURTROOM 148-51 (1999) [hereinafter RAPE AND CULTURE] (explaining reality and consequences of Bill of Rights provisions governing the actions of all three branches of government); Tracey Maclin, The Central Meaning of the Fourth Amendment, 35 WM. \& MARY L. REV. 197 (2000) (arguing that the Court's undue deference to police judgment is inconsistent with the Court's recognition of the Fourth Amendment as a fundamental right).

385. AMERICAN BAR ASSOCIATION TASK FORCE ON TECHNOLOGY AND LAW ENFORCEMENT, TEnTATIVE Draft Standards CONCERning TeChNOlOGiCAlly-Assisted Physical SURVEILlANCE (Tentative Draft 1997) §§ 2-6.2(e), 2-6.3(b) [hereinafter ABA TASK ForCE]. The proposed standards treat various types of video surveillance differently, for example, requiring greater protections for covert surveillance in the home. See id. at § 2-6.3(a); Slobogin, supra note 48, at 440-42. Because I do not here attempt a thorough analysis of the ABA Standards, using them merely for purposes of illustration, I here address only those portions of the Standards directly governing video surveillance on public streets. Although the standards do permit video surveillance where one of the monitored parties has consented to it, that consent doctrine apparently applies to surveillance of the home and similar locations rather than to video observation of crowds on public streets. See Slobogin, supra note 48, at 442; ABA TASK FORCE, supra note 385, at $\$ 2-6.3$ (b) (apparently presuming one or a few individuals' consent to be irrelevant to whether on-street surveillance protections apply). 
fore and during the surveillance, to express its views of the surveillance and to propose changes in its execution. ${ }^{386}$ This provision seems to contemplate regulation of activities like the video surveillance of Ybor City. The Standards additionally prohibit an arbitrary or discriminatory manner of surveillance, and require (1) its limitation to the scope necessary to achieving its objectives; (2) its termination when the objectives are achieved; (3) disclosure of information only for designated lawful purposes; (4) the use of administrative rules and sanctions to promote accountability; and (5) the crafting of written instructions to guide officer implementation. ${ }^{38}$

Under the approach articulated in this article, the Ybor City activities would be constitutionally regulated, thus not leaving it entirely to the whim of the legislative process whether to adopt standards like those articulated by the ABA. I do not necessarily endorse every jot of the ABA proposal, but it does have many merits.

First, by requiring adequate notice of the location and capability of the cameras, the proposal permits objecting citizens to steer clear of the areas where the cameras are used. This is, of course, a significant cost to impose on persons who otherwise might want to visit nightlife centers like Ybor City. ${ }^{388}$ The cost is permitted only if the cameras are reasonably likely to achieve a legitimate law enforcement objective, presumably putting the burden on the state to produce evidence of a real problem and further evidence that the cameras create a significant probability of addressing that problem. ${ }^{389}$ Since I view video surveillance in public places as impinging upon a protected fundamental right, I am not sure that the "reasonable likelihood of success" and "legitimate objective" standards are ordinarily adequate. ${ }^{390}$ Where there is significant evidence of a terrorist threat, however, this seems to be a compelling interest. Moreover, given the enormity of the danger in the case of terrorism, the reasonable likelihood of success standard might also make sense, so long as adequate consideration is given to the question whether viable alternative solutions to the problem of terrorism would not alone be an effective solution. ${ }^{391}$

Second, the standard does not equate majority will with the scope of legal protection. Citizens are involved in that they are periodically consulted to express their views on the video surveillance. No vote is taken, however, to de-

386. ABA TASK FORCE, supra note 385, at $\S 2-6.3(\mathrm{~b})$.

387. Id. at $\S 2-6.1(\mathrm{~d})-(\mathrm{g})$.

388. See supra text accompanying notes 1-18 (describing the Ybor City controversy); Part III.C (describing the social costs of invading "privacy in public").

389. Cf. TASLITZ \& PARIS, supra note 27, at 364-66 (explaining the significance of evidence that a regulatory problem exists when crafting and justifying administrative search rules, albeit a factor the weight of which the high Court has been inconsistent in addressing).

390. See Konvitz, supra note 257, at 148 (explaining the doctrine that fundamental rights can be infringed only if the infringement is the least restrictive alternative to achieving a compelling governmental interest).

391. See id. (explaining the importance of least restrictive alternatives analysis); TASLITZ \& PARIS, supra note 27, at 368 (stating that the availability of less, if not the least, restrictive alternatives is a relevant, albeit not determinative, factor in the Court's current Fourth Amendment jurisprudence). 
termine whether, when, where, and for what purposes the surveillance may be done. ${ }^{392}$ Instead, the politically accountable officials may proceed only if they find a reasonable likelihood of achieving a legitimate governmental objective, regardless of the majority's will. This may reduce the chances of racial discrimination in application, for example, discouraging the use of video surveillance in only black but not in white neighborhoods. ${ }^{39}$

At the same time, the continuing involvement of the citizenry in monitoring the surveillance via periodic hearings can serve as a powerful restraint on governmental abuses. ${ }^{394}$ Indeed, because the relevant "public" is defined as those "to be affected by the surveillance," ${ }^{395}$ it would seem to be the case that racial minorities singled out for surveillance would then be precisely those who are entitled to a public forum in which to raise their objections. Moreover, the standards flatly prohibit arbitrary or racially discriminatory applications. ${ }^{396}$ The Task Force drafting committee wisely recognized that leaving the decisions to "politically accountable officials" is an insufficient safeguard. Independent monitoring by the affected citizenry serves important adjunct functions. As the Task Force's Reporter explained, "involvement of the public affected by the surveillance can act as a check on elitist decision-making, provide useful information as to the scope of the problem, encourage a sense of community involvement, and diminish the discomfort associated with the surveillance by increasing understanding of its nature and purpose." ${ }^{\prime 397}$ At the same time, because the public serves a monitoring rather than a veto function, officials with adequate justification can still act quickly and effectively to meet significant threats to safety like those posed by potential terrorist actions. ${ }^{398}$

Nor does the standard ignore "individual sovereignty," the idea that Fourth Amendment rights vest at least partly in individuals. ${ }^{399}$ Remember that the harm to individual sovereignty rests not so much in the search or seizure as in the unjustified infringement upon individual privacy. ${ }^{400}$ Ordinarily, such justification requires individualized suspicion. ${ }^{401}$ But where we have no idea who is about to commit a crime, or where the wrongdoer may be, or precisely when he will strike, and where the danger to human life is grave, there may be no other

392. Slobogin, supra note 48 , at $442-43$.

393. Sherry Colb discusses the "targeting harm" that occurs when individuals are singled out by the police for searches or seizures without adequate justification. Colb, Targeting Harm, supra note 44, at 1491-95. I am suggesting here, relying on my analysis in Part III.B of this article, that groups can experience targeting harm as well. The ABA standard helps to reduce the risk of group targeting harm.

394. Andrew E. Taslitz, Slaves No More! The Implications of the Informed Citizen Idea for Discovery Before Fourth Amendment Suppression Hearings, 15 GA. ST. U. L. REV. 707, 757-61 (1999) [hereinafter Slaves No More!] (commenting on the Fourth Amendment role of a "monitorial citizenry").

395. ABA TASK FORCE, supra note 385, at $§ 2-6.3$ (b).

396. Id. at $\$ \S 2-6.1,2-6.2$.

397. See Slobogin, supra note 48, at 442-43.

398. See Taslitz, Slaves No More!, supra note 394, at 728; Andrew E. Taslitz, Independent Auditors, Race, and the Fourth Amendment, 66 LAW \& CONTEMP. PROBS (forthcoming 2002).

399. See supra notes 250-56 and accompanying text (discussing "individual sovereignty" idea).

400. See supra note 324 and accompanying text (making this point).

401. See TASLITZ \& PARIS, supra note 27, at 83. 
reasonable way but surveilling many innocents to find the guilty and therefore protect against catastrophe. ${ }^{402}$ The Court has recognized as much in permitting random drug-testing of persons in safety-sensitive jobs and suspicionless drunkdriving roadblocks as ways to protect human life. ${ }^{403}$ Importantly, the Court has reached these conclusions without excluding drug tests and roadblocks from constitutional protection and while still requiring restrictions against arbitrary police actions in such cases. ${ }^{404}$ Individualized justice is thus sacrificed only for compelling reason and without completely abandoning procedural protections for the individual.

The ABA standard is unclear concerning what remedies, if any, would be available to a person aggrieved by video surveillance violative of the standard. That ambiguity seems to stem from the Task Force's acceptance of the idea that regulation in this area is within the discretion of legislatures rather than within the mandate of the Constitution. Under my approach, the opposite would be true. Courts would be available to consider suppression motions in criminal cases or civil damages suits where police failed to act consistently with legislatively-adopted standards necessary to meeting constitutional minima. ${ }^{405}$

Similarly, courts could act where no standards were adopted in the first place. It may be that the legislature is better equipped than the judiciary to enact comprehensive standards for when and how to engage in video surveillance. ${ }^{406}$ Nevertheless, courts can insist on such standards and can provide broad guidelines for what such standards must accomplish to meet constitutional minima. Professor Erik Luna refers to this as courts providing "constitutional roadmaps" - that is, rather than simply invalidating a statute or practice, the Court also provides a broad roadmap for how future legislative or executive actions can address a social problem without treading on constitutional freedoms. ${ }^{407}$ Luna does not believe that such roadmaps are always wise, but he believes that they at least sometimes make sense and have been used effectively in the area of criminal procedure. . $^{08}$

One illustration might be Berger v. New York. ${ }^{409}$ There, Berger challenged evidence acquired through the use of a recording device installed in an attorney's office. The device had been installed pursuant to a warrant issued in accordance with a New York statute governing "eavesdropping warrants." The

402. Id. at 368-70 (discussing the Supreme Court's partial justification of suspicionless drunk driving roadblocks to protect public safety on the grounds that it would otherwise be difficult to identify potentially dangerous offenders); NRC Report, supra note 383, at 117-53, 156-58 (rising dangers from terrorism might sometimes justify greater intrusions on Fourth Amendment interests).

403. See TASLITZ \& PARIS, supra note 27, at 364-70 (discussing case law).

404. Id.

405. Id. at 479-82 (summarizing current remedies for Fourth Amendment violations).

406. Cf. Taslitz, RAPE AND CULTURE, supra note 384, at 148-51 (arguing for a "legislative constitution"); Taslitz, Slaves No More!, supra note 394, at 776-79 (arguing that comprehensive discovery reform relevant to Fourth Amendment suppression hearings is best done by legislatures).

407. See generally Luna, Constitutional Roadmaps, supra note 258.

408. Id. at $1238-42$.

409. 388 U.S. 41 (1967). 
Court struck down the warrant-authorizing statute as overbroad, implicitly holding that intangibles such as private conversations fall within the scope of the Fourth Amendment. At the same time, the Court recited with some specificity both how the New York eavesdropping warrants fell short of usual constitutional protections and what changes might render New York's effort constitutional. ${ }^{410}$ Concerning the latter point, the Court approvingly cited its holding in Osborn v. United States, ${ }^{411}$ where recordings of conversations were found admissible because "[ $\mathrm{t}]$ he recording device was ... authorized 'under the most precise and discriminate circumstances, circumstances which fully met the requirements of particularity' of the Fourth Amendment." 412 The Court specifically noted that the recording device in Osborn was installed with the authorization of two judges acting jointly and only after they received an affidavit of a witness setting out in detail prior conversations of a criminal nature between the witness and the defendant. Moreover:

\begin{abstract}
the order described the type of conversation sought with particularity, thus indicating the specific objective of the Government in entering the constitutionally protected area and the limitations placed upon the officer executing the warrant. Under it the officer could not search unauthorized areas; likewise, once the property sought, and for which the order was issued, was found the officer could not use the order as a passkey to further search. In addition, the order authorized one limited intrusion rather than a series or a continuous surveillance.... Moreover, the order was executed by the officer with dispatch, not over a prolonged and extended period. In this manner no greater invasion of privacy was permitted than was necessary under the circumstances. Finally, the officer was required to and did make a return on the order showing how it was executed and what was seized. ${ }^{413}$
\end{abstract}

Congress quickly responded to the Court's signal that a properly designed electronic surveillance statute could satisfy the Fourth Amendment. ${ }^{414}$ Shortly after Berger, Congress enacted "Title III," also known as the "Federal Wiretap Act." ${ }^{415}$ Though the Act is often ambiguous and has many weaknesses, it attempted to follow the Berger Court's guidance and has, from the late 1960s on, been the dominant statute regulating the use of mechanical devices to intercept wire, oral, and electronic communications. ${ }^{416}$ A similar judicial roadmap could likewise lead to a Federal Public Video Surveillance statute or numerous state law equivalents.

Terrorism is a multi-faceted problem requiring a multi-faceted solution. Freezing assets, altering foreign policy, covert military action, target-hardening to make doing damage more difficult, and improved security procedures for screening passengers and luggage at airports are but a few of the components of

410. Id. at $43-45,56-57$.

411. 385 U.S. 323 (1966).

412. Berger, 388 U.S. at 56 (quoting Osborn, 385 U.S. at 329 n.7).

413. Id. at 56-57.

414. See TASLITZ \& PARIS, supra note 27 , at 248.

415. Id. (discussing 18 U.S.C. $\S \S 2510-20$, (1994)).

416. Id. at 248-49. 
a sound anti-terrorism policy. ${ }^{417}$ Wider erosions of civil liberties may not be necessary. As former Attorney General of the United States, Phillip Heyman, has explained:

$[O]$ ne of the great dangers of terrorism in every democracy is that it may lead, as it is often intended by the terrorists, to self-destructive actions. We must learn never to react to the limited violence of small groups by launching a ... [campaign] in which we destroy our unity as a nation or our trust in the fairness and restraint of the institutions of the U.S. government that control legitimate force. ${ }^{4}$

The revised conception of privacy articulated here should aid, not hinder, the effort to achieve a fair balance between safety and individual liberty. Constitutional regulation will promote more careful, deliberate legislative action and dialogue among the three branches of government. We need not win the war against terrorism by sacrificing our constitutional soul.

417. See generally NRC Report, supra note 383; DEMPSEY \& COLE, supra note 19; HEYMANN, supra note 19; PAUl R. PILlar, TERRORISM AND U.S. ForeIgN POLICY (2001).

418. HEYMANN, supra note 19, at 158. 